\title{
NEKA PITANJA O IMOVINSKIM ODNOSIMA BRAČNIH DRUGOVA U HRVATSKOM I TALIJANSKOM OBITELJSKOM PRAVU
}

Prof. dr. sc. Lucia Ruggeri*

Doc. dr. sc. Sandra Winkler**

\author{
UDK: $347.626(450)(497.5)$ \\ https://doi.org/10.30925/zpfsr.40.1.7 \\ Ur.: 28. siječnja 2019. \\ Pr.: 20. veljače 2019. \\ Izvorni znanstveni rad
}

\section{Sažetak}

U radu će se analizirati neka pitanja o imovinskim odnosima bračnih drugova $u$ hrvatskom i talijanskom obiteljskom pravu. Ponajprije će se razmotriti postojeće uređenje imovinskih odnosa bračnih drugova u hrvatskom obiteljskom pravu. Zatim će se domaća pravna rješenja usporediti s talijanskim obiteljskim zakonodavstvom u kontekstu uređenja imovinskih odnosa u obitelji, ističući najvažnija pitanja koja se javljaju u praktičnoj primjeni obiteljskopravnih rješenja. U nastavku rada autorice će na temelju pronađenih odgovora, komparativnom metodom istraživanja, pokušatiprepoznati prednosti inedostatke dvaju nacionalnih zakonodavnih okvira u kontekstu imovinskih odnosa u braku te priupitati se je li potrebno dodatno razraditi ovo područje. $O$ rezultatima provedene analize će se u završnom dijelu rada promišljati u svjetlu stupanja na snagu dviju europskih Uredaba o imovinskopravnim odnosima bračnih drugova i registriranih partnera, kojima će se pojaviti novi pravni izazovi vezani za rješavanje različitih pitanja uređenja imovinskih odnosa u obiteljima s prekograničnim implikacijama. U zaključcima će autorice ponuditi moguća rješenja kojima bi se dodatno unaprijedila postojeća uređenja imovinskih odnosa u obitelji s posebnim naglaskom na prekograničnu dimenziju tih odnosa.

Ključne riječi: obitelj; imovinski odnosi; bračni ugovor; bračni drugovi; izvanbračni drugovi; životno partnerstvo; Uredba 2016/1103; Uredba 2016/1104.

\footnotetext{
* Dr. sc. Lucia Ruggeri, redovita profesorica, Sveučilište u Camerinu, Pravni fakultet; lucia. ruggeri@unicam.it.

** Dr. sc. Sandra Winkler, docentica, Sveučilište u Rijeci, Pravni fakultet; swinkler@pravri.hr. „Ovaj je rad sufinanciran projektom iz Justice Programa (2014-2020) Europske unije PSEFS - Personalized Solution in European Family and Succession Law n. 800821-JUST-AG-2017/ JUST-JCOO- AG-2017. Sadržaj ovog dokumenta isključivo je stajalište autora za koja sami odgovaraju. Europska komisija ne prihvaća bilo koju odgovornost za namjenu sadržanih informacija. (This paper has been co-founded by the European Union's Justice Programme (2014-2020) Project PSEFS - Personalized Solution in European Family and Succession Law
} 


\section{UVODNA RAZMATRANJA}

U domaćem, komparativnom i u europskom pravu bilježi se rastući interes za pravna pitanja koja proizlaze iz uređenja imovinskih odnosa u obitelji. U ovom će se radu ponajprije analizirati postojeće uređenje imovinskih odnosa bračnih drugova u hrvatskom obiteljskom pravu. Zatim će se isto usporediti s talijanskim obiteljskim pravom. U tom pogledu prikazat će se normativni okvir imovinskopravnih odnosa u tom inozemnom pravnom sustavu te će se istaknuti najvažniji problemi koji se javljaju u tamošnjoj primjeni imovinskog obiteljskog prava.

Preciznije, na temelju pronađenih odgovora, komparativnom metodom istraživanja, pokušat će se prepoznati prednosti i nedostatci postojećega domaćeg zakonodavnog okvira u kontekstu imovinskih odnosa u braku te utvrditi jesu li recentne reforme $u$ hrvatskom pravnom sustavu doprinijele unaprjeđenju zaštite imovinskih prava i obveza u obitelji ili je potrebno dodatno razraditi ovo područje. Nadalje će se nastojati odgovoriti na isto pitanje u talijanskom pravnom sustavu. Potreba razmatranja i usporedbe različitih imovinskih režima bračnih drugova ne počiva isključivo na teorijskoj „,vježbi“ komparacije. Naprotiv, postoje važni praktični razlozi zbog kojih je korisno usporediti različite pravne sustave. Stupanjem na snagu 29. siječnja 2019. dviju europskih uredbi u kontekstu imovinskopravnih odnosa bračnih drugova i registriranih partnera pojavit će se, posebno pred praktičarima, novi pravni izazovi vezani za rješavanje različitih pitanja uređenja imovinskih odnosa u obiteljima s prekograničnim implikacijama. ${ }^{1}$

$\mathrm{S}$ time u vezi, u ovom se radu izabralo razmotriti hrvatski i talijanski pravni sustav, jer se radi o državama članicama Unije koje u praksi imaju relevantan broj obitelji s prekograničnim implikacijama. ${ }^{2}$ Bit će zanimljivo priupitati se na koji će način stupanje na snagu spomenutih uredaba, a ponajprije mislimo na Uredbu br. 1103/2016, utjecati na pojedinačne pravne sustave, odnosno na primjenu nacionalnih propisa. ${ }^{3}$ No, kako bi se u nekom daljnjem istraživanju moglo odgovoriti na to

n. 800821-JUST-AG-2017/JUST-JCOO-AG-2017. The content of this document represents the views of the authors only and is their sole responsibility. The European Commission does not accept any responsibility for use that may be made of the information it contains).

1 Uredba Vijeća (EU) 2016/1103 o provedbi pojačane suradnje u području nadležnosti, mjerodavnog prava te priznavanja i izvršenja odluka u stvarima bračnoimovinskih režima i Uredba Vijeća (EU) 2016/1104 o provedbi pojačane suradnje u području nadležnosti, mjerodavnog prava te priznavanja i izvršenja odluka $u$ stvarima imovinskih posljedica registriranih partnerstava, SL L 183, 8.7.2016. Ex plurimis, o tim pitanjima v. Dutta, A., Weber, J., Die Europäischen Güterrechtsverordnungen, Beck, 2017., Pintens, W., Matrimonial property Law in Europe, u: Boele-Woelki, K. i dr. (ur.), The Future of Family property in Europe, Cambridge - Antwerp - Portland, Intersentia, 2011., str. 19-46.

2 Prema provedenom istraživanju i na temelju podataka dobivenih iz talijanskog Generalnog konzulata u Rijeci, samo na području za koje je mjesno nadležno ovo konzularno tijelo u proteklih je deset godina sklopljeno više od dvjesto brakova među talijanskim i hrvatskim državljanima. Ta bi brojka bila zacijelo mnogo veća kad bi se takvo istraživanje provelo ne na lokalnoj, već na nacionalnoj razini razmatrajući sve brakove sklopljene i u Republici Hrvatskoj i u Republici Italiji. Ovo je samo skroman pokazatelj koji već na lokalnoj razini ukazuje na postojanje brakova s prekograničnom implikacijom koja se odnose na ova dva pravna sustava.

3 Winkler, S., Il diritto di famiglia, u Benacchio, G. A., Casucci, F. (ur.), Temi e Istituti di Diritto 
pitanje, nužno je krenuti u analizu odabranih pravnih sustava radi raščlambe uređenja imovinskih odnosa te eventualnog prepoznavanja sličnosti i različitosti, koje bi itekako mogle biti relevantne pri budućoj primjeni europskoga zakonodavstva u tim državama članicama.

Premda oba pravna poretka pripadaju kontinentalno europskom krugu, hrvatsko i talijansko obiteljsko pravo se po mnogočemu razlikuju. Ponajprije valja naglasiti da su u hrvatskom pravnom sustavu obiteljskopravni odnosi uređeni posebnim Obiteljskim zakonom te je obiteljsko pravo zasebna grana prava u odnosu na građansko pravo; dok talijanski pravni sustav uređuje privatno pravo (a time se misli na: stvarno, obvezno, nasljedno, obiteljsko, radno, trgovačko...) jednim jedinim opsežnim građanskim zakonikom (codice civile). ${ }^{4}$ Prima facie moglo bi se izvesti kako su talijanska pravna rješenja koherentnija i potpunija s obzirom na to da nalaze uređenje u istom zakoniku koji uređuje također stvarnopravna i obveznopravna pitanja koja se odnose na bračne drugove kao i na sve ostale subjekte. Ipak će se dokazati da u oba pravna sustava prevladava potreba posebnog normiranja tih odnosa, pravilima kojima se ističe posebnost obiteljskih odnosa. Obiteljski sustav unutar talijanskoga građanskog zakonika moglo bi se reći da gotovo samostalno regulira odnose u obitelji jer ih smatra takvima da se ne mogu zbog predmeta, prirode i obilježja podvesti pod uređenje obveznog i stvarnog prava.

S druge strane, valja naglasiti da hrvatsko obiteljsko pravo bivajući uređeno zasebnim zakonom ponekad pati od posljedica fragmentarnosti i nekoherentnosti postojećih pravnih rješenja koja proizlaze iz kombinirane primjene odredaba koje se nalaze u različitim propisima. Ipak, prednost je postojanja zasebnoga obiteljskog zakonodavstva ta da se mogu puno brže prihvatiti nova, modernija pravna rješenja, pa tako slijediti suvremeni trendovi u normiranju obiteljskih odnosa. Primjerice, u oba će se pravna sustava analizirati ugovorno uređenje imovinskih odnosa među bračnim drugovima i dokazat će se kako hrvatski propisi u većoj mjeri odgovaraju težnjama afirmiranja autonomije volje bračnih drugova u odnosu na talijanska pravna rješenja kojima de facto talijanski bračni drugovi ne mogu sklopiti bračni ugovor, odnosno imaju prilično ograničenu slobodu ugovornog uređenja imovinskih odnosa.

\section{IMOVINSKI ODNOSI BRAČNIH DRUGOVA U HRVATSKOM OBITELJSKOM PRAVU}

Hrvatski zakonodavac posvećuje imovinskim odnosima bračnih drugova svega četrnaest članaka (od 34. do 46. članka) Obiteljskoga zakona. ${ }^{5}$

Usporedbe radi, talijanski codice civile uređuje materiju člancima od 177 . do 230.ter, što znači s više od pedeset odredaba.

Stajalište autora je da nije potrebno, niti smisleno, slijediti postojeći trend (bilo nacionalan, bilo globalan) hipernormiranja i detaljiziranja, jer to dovodi do raznih poteškoća u tumačenju i primjeni propisa. Također ne mislimo da se može pitanje

Privato dell'Unione Europea, Torino, Giappichelli, 2017., str. 301.

4 Codice civile iz 1942. godine (Regio Decreto 16 marzo 1942 - XX, n. 262).

5 Obiteljski zakon, NN, br. 103/2015. 
kvalitetnog uređenja imovinskih odnosa svesti na količinu odredaba. Ipak, iako se u posljednjih nekoliko desetljeća ovaj dio hrvatskoga obiteljskog prava razvija, valja istaknuti da ima prostora za daljnji napredak. U prošlosti su imovinski odnosi smatrani manje bitnim dijelom obiteljskopravnih odnosa, stoga su se uređivali većinom strogim propisima uz ograničenu stranačku slobodu. ${ }^{6}$ Jasno se ističe u doktrini kako su dugo vremena u odnosu na neka poredbena rješenja u tuzemnom pravnom sustavu imovinski odnosi bili pojednostavljeni i šturo uređeni.?

To se u posljednjim desetljećima promijenilo, pa se sve veća pozornost pridaje tom dijelu obiteljskog zakonodavstva. ${ }^{8}$ Osnovna su dostignuća tog procesa razvoja imovinskog obiteljskog prava ostvarena zahvaljujući zakonodavnoj aktivnosti i sudskoj praksi, a mogu se najbolje ogledati u afirmiranoj zaštiti autonomije volje bračnih drugova glede uređenja međusobnih imovinskih interesa, kao i u zaštiti prava poštenih trećih osoba.

Pravna analiza uređenja imovinskih odnosa bračnih drugova ne može se provesti mimo raščlambe temeljnih načela na kojima počiva cjelokupno obiteljsko pravo. Naime, ne valja promatrati imovinske odnose poput odvojene cjeline u odnosu na sferu osobnih prava bračnih drugova. Upravo radi tih specifičnih odnosa koji se zbog intimne naravi razlikuju od ostalih, norme koje uređuju imovinu u braku imaju specifična obilježja. U tom pogledu prof. Korać Graovac naglašava da „životna zajednica bračnih drugova u pravilu obuhvaća zajedničko domaćinstvo u kojem se ispunjava ekonomska funkcija braka“. Naime, pojmovi „životna zajednica“ i „ekonomska funkcija braka“ snažno obilježavaju spoj osobnih i imovinskih prava i obveza u obitelji.

Ustav Republike Hrvatske člankom 62. naglašava da su brak i odnosi u braku uređeni zakonom, a Obiteljski zakon je taj koji prije ostalih ih uređuje kroz ranije spomenute članke i svoje uvodne odredbe. ${ }^{9}$ Naime, kako ističe članak 4. važećega Obiteljskog zakona „solidarnost je temeljno načelo obiteljskog života. Svi članovi obitelji moraju se uzajamno poštovati i jedan drugome pomagati“. Nesporno je da se pojam „pomaganja“ tumači i u moralnom i u materijalnom smislu riječi. Načelu obiteljske solidarnosti prethodi u Obiteljskom zakonu načelo ravnopravnosti muškarca i žene. Zakonodavac je nedavnom reformom obiteljskog zakonodavstva izričito propisao člankom 3., stavkom 1. da ,žena i muškarac imaju međusobno jednaka prava i dužnosti u svim obiteljsko-pravnim odnosima, a posebno u odnosu na roditeljsku skrb".

Ratio legis svake od postojećih odredaba kojom su regulirani imovinski odnosi bračnih drugova potvrđuje kako načelo obiteljske solidarnosti i načelo ravnopravnosti

6 Korać Graovac, A., Imovinski odnosi bračnih drugova, u Alinčić, M., i dr., Obiteljsko pravo, Zagreb, Narodne novine, 2007., str. 498.

7 Loc. cit.

8 O razvoju prava na autonomiju u bračnom imovinskom pravu upućuje se na Čulo, A., Radina, A., Valjanost bračnog ugovora, u: Rešetar, B., Župan, M., Imovinskopravni aspekti razvoda braka - hrvatski, europski i međunarodni kontekst, Osijek, Pravni fakultet u Osijeku, 2011., str. 140 .

9 Ustav Republike Hrvatske, NN, br. 56/1990., 135/1997., 08/1998., 113/2000., 124/2000., 28/2001., 41/2001., 55/2001., 76/2010., 85/2010., 05/2014. 
muškarca i žene, premda poštujući stranačku slobodu ugovaranja, čine jezgru ponuđenih pravnih rješenja u domaćem obiteljskom pravu.

\subsection{Zakonsko uređenje imovinskih odnosa bračnih drugova}

Prema hrvatskom obiteljskom pravu bračni drugovi mogu urediti međusobne imovinske odnose na dva načina: zakonskim ili ugovornim uređenjem imovinskih odnosa. Valja spomenuti kako se iste odredbe primjenjuju i na izvanbračne zajednice regulirane člankom 11. Obiteljskog zakona. Na zajednice osoba istog spola (bilo registrirane ili neformalne) primjenjuju članci od 50. do 54. Zakona o životnom partnerstvu osoba istog spola, koji sadrže uređenje istovjetno onome iz Obiteljskog zakona, odnosno upućuje na primjenu toga Zakona za sva pitanja koja nisu izričito normirana. ${ }^{10}$

Već iz prve odredbe koja otvara dio Obiteljskog zakona pod naslovom „imovinski odnosi bračnih drugova“ (čl. 34.) razvidan je dispozitivan karakter ovih odredaba. Naime, na imovinske će se odnose bračnih drugova primjenjivati odredbe tog zakona ako bračni drugovi nisu te odnose uredili bračnim ugovorom. Ergo, bračni drugovi imaju slobodu ugovoriti međusobno različito uređenje njihovih imovinskih interesa. Naprotiv, ako bračni drugovi ne odluče različito urediti međusobne imovinske interese, primijenit će se zakonski režim koji je propisan člancima od 35. do 39. Obiteljskoga zakona, kojima se definiraju bračna stečevina i vlastita imovina (čl. 35., 36. i 39.), propisuju se pravila upravljanja bračnom stečevinom (čl. 37.) te se propisuje podredna primjena stavnornopravnih i obveznopravnih propisa (čl. 38.). ${ }^{11}$

Prvi stavak članka 36. Obiteljskog zakona propisuje kako bračnu stečevinu čini imovina koju su bračni drugovi stekli radom za vrijeme trajanja bračne zajednice ili potječe iz te imovine. ${ }^{12} \mathrm{U}$ usporedbi s talijanskim pravom, hrvatski zakonodavac postavlja restriktivniju osnovu stjecanja bračne stečevine: rad. No, ono što se također razlikuje i što je zanimljivo u hrvatskom obiteljskopravnom rješenju jest vremensko vezivanje stjecanja bračne stečevine za trajanje „bračne zajednice“, a

10 Zakon o životnom partnerstvu osoba istog spola, NN, br. 92/2014.

11 Detaljnu analizu nudi: Belaj, V., Bračna stečevina po obiteljskom zakonu, Zbornik Pravnog fakulteta Sveučilišta u Rijeci, vol. 23., 1/2002, str. 179-200.

12 Uobičajenim predmetom bračne stečevine smatraju se: plaća, vlasništvo nad pokretninama i/ili nekretninama stečenima na osnovi rada, vlasništvo nad trgovačkom društvu ili obrtu, ušteđevina, prihodi od bračne stečevine itd... Korać Graovac, A., op. cit., str. 505, ističe kako je zanimljivo da ulaze u ovu kategoriju i predmeti za osobnu uporabu, što je potpuno oprečno regulirano $u$ talijanskom pravu (čl. 179. codice civile). O predmetu bračne stečevine sve će se češće u praksi pojavljivati pitanja koja se odnose na neke nove kategorije, poput prava na temelju dionica i dividenda trgovačkih društava. Upućuje se također na Rešetar, B., Josipović, U., Sporna pitanja bračne stečevine s osvrtom na bankovne ugovore bračnih drugova, Zbornik Pravnog fakulteta u Splitu, vol. 50, 1/2013, str. 115-138. Sudska praksa često tumači predmet bračne stečevine. Primjerice, često se u sudskoj praksi pojavljuje pitanje ulazi li vlasništvo stečeno na temelju ugovora o doživotnom ili dosmrtnom uzdržavanju u bračnu stečevinu. U tom pogledu ugovor o doživotnom uzdržavanju u svojim bitnim obilježjima tumači se kao naplatan pravni posao. Upućuje se na: VSRH Rev X 29/2015-2; VSRH Rev 2097/2011-2 dostupno na: www.iusinfo. hr, posjećeno 7.1.2019. 
bračnu se zajednicu kvalificira ,životnim sadržajem braka“ ${ }^{13}$ Talijanski pravni sustav propisuje znatno veće razdoblje unutar kojeg se stječe zajednička imovina. ${ }^{14}$ Skreće se pozornost na to da hrvatski Obiteljski zakon ne govori o braku, već o bračnoj zajednici. ${ }^{15}$ Polazeći od očite konstatacije da se prestanak bračne zajednice i prestanak braka često ne podudaraju, ovim rješenjem zakonodavac usko povezuje imovinske odnose s ranije spomenutim načelom obiteljske solidarnosti. Ako više nema bračne zajednice, odnosno one životne zajednice u kojoj se ostvaruje ekonomska funkcija braka, onda nema ni svrhe postojanju zakonskog režima uređenja imovinskih odnosa bračnih druga ${ }^{16}$ Kako bi se shvatio razlog ovakvog uređenja, valja pročitati odredbu iz stavka 3., članka 36. koja glasi: „bračni su drugovi jednakim dijelovima suvlasnici bračne stečevine, ako nisu drugačije ugovorili“" ${ }^{17}$ Ovom se normom afirmiraju načelo obiteljske solidarnosti i načelo ravnopravnosti žene i muškarca, budući da propisuje neoborivu presumpciju suvlasništva u jednakim dijelovima neovisno o konkretnom doprinosu svakoga bračnog druga. ${ }^{18} \mathrm{U}$ prošlosti se u obiteljskom zakonodavstvu bračnu stečevinu uvrštavala u zajedničku imovinu, što je značilo da su se sve do stupanja na snagu Obiteljskog zakona iz 1998. udjeli bračnih drugova u imovini mogli odrediti, ali nisu bili određeni do eventualnog sporazuma bračnih drugova ili sudskog postupka. ${ }^{19}$ Naprotiv, posljednjih dva desetljeća, iako se u tom kratkom razdoblju izmijenilo čak četiri obiteljskih zakona, što ne ide u prilog očuvanju kontinuiteta pravnih rješenja niti postignutih usuglašenih stajališta u sudskoj praksi koji uvelike pomažu u daljnjim naporima razvoja ovih aspekata obiteljskog prava, suvlasništvo je

13 Korać Graovac, A., op. cit., str. 502-503.

14 Misli se na čl. 177. codice civilea.

$15 \mathrm{U}$ tom pogledu valja spomenuti da je davno obiteljski zakonodavac zamijenio pojam „braka“ $\mathrm{s}$ pojmom „bračna zajednica“. Preciznije, čl. 271. Zakona o braku i porodičnim odnosima, NN, br. 11/1978, 27/1978, 45/1989 i 59/1990 zamjenjuje se pojam brak s bračnom zajednicom. V. Mladenović, M., Porodično pravo, knjiga II, Beograd, Privredna štampa, 1981., str. 648, koji doslovno stiče da „pod brakom se smatra samo ‘živi' brak, onaj koji de facto postoji, a ne samo formalno". Nadalje, upućuje se na Prokop, A., Komentar osnovnom zakonu o braku, I, Zagreb, 1959., str. 28. Autorica ističe kako se već za vrijeme primjene Osnovnog zakona o braku, Službeni list FNRJ, br. 29/1946, kad se u članku 10. navodio „brak“, a ne kasniji termini „bračna zajednica“, razvijala sudska praksa kojom se više nije vidjela u toj odredbi svrha stjecanja zajedničke imovine ako to nije bila istinska stečevina bračne zajednice.

16 Potrebno je pojasniti da nije svaki prekid bračne zajednice nužno takve prirode da obilježava kraj bračnog odnosa. Kao što je jasno isticala prof. Prokop, „drugačija je situacija ako bračni drugovi samo privremeno odvojeno žive, a da uopće nije došlo do poremećenosti bračnih odnosa“. „Tada ustvari nema prekida bračne zajednice (... "“. Doslovno preuzeto, loc. cit.

17 U sudskoj se praksi jasno potvrđuje djelovanje ove neoborive presumpcije. U tom pogledu izdvajamo među ostalim: Županijski sud u Splitu, Gž Ob-97/16, od 15.IX.2016.

18 Usp. Korać Graovac, A., op. cit., str. 503.

19 Obiteljski zakon, NN, br. 162/1998. počeo se primjenjivati 1. srpnja 1999., tako da je u razdoblju između njegova stupanja na snagu i primjene postala određena vacatio legis koja je bila predmetom više tumačenja u literaturi. Usp. Hrabar, D., Retroaktivnost i stečena prava prema obiteljskom pravu, Hrvatska pravna revija, 5/2005, str. 38-46. Kačer, H., Jedna dvojba glede primjene ObZ ili imaju li odredbe ObZ o bračnoj stečevini povratni učinak, Pravo i porezi, 12, 1999., god. 8., str. 26-32. O ranijem zakonskom uređenju imovinskih odnosa bračnih drugova upućuje se na: Hrabar, D., Režim stjecanja i diobe imovine bračnih drugova u hrvatskom i poredbenom pravu, Zbornik Pravnog fakulteta u Zagrebu, 44, 3/1994, str. 235-252. 
zamijenilo zajedničko vlasništvo. No, obiteljsko zakonodavstvo propisujući isključivo ovu presumpciju iuris et de iure uz nekoliko dodatnih normi glede upravljanja s imovinom nužno upućuje na primjenu stvarnopravnih propisa u pogledu uređenja brojnih aspekata suvlasništva koji nisu drukčije propisani Obiteljskim zakonom. ${ }^{20}$

Vidjet će se kasnije kako talijanski codice civile ne propisuje istovjetno rješenje. Naprotiv, kvalificira bračnu stečevinu kao zajedničko vlasništvo i ne predmnijeva paritetne dijelove, što nedvojbeno asocira na rješenje koje je postojalo u ne tako davnoj povijesti tuzemnog obiteljskog prava. Naime, pravno rješenje koje je u našoj prošlosti izazivalo mnoge poteškoće u praktičnoj primjeni, posebno u zaštiti trećih osoba, još i danas u talijanskom pravnom sustavu budi iste prijepore.

Zakonski režim bračnih drugova poznaje osim bračne stečevine i vlastitu imovinu. Osim imovine koju bračni drugovi imaju u trenutku sklapanja braka, u vlastitu se imovinu ubraja i sva imovina koju je bračni drug stekao tijekom bračne zajednice na osnovi različitoj od rada (primjerice, nasljeđivanjem ili darovanjem). ${ }^{21} \mathrm{U}$ vlastitu imovinu ubrajaju se i autorska djela. S time u vezi, valja se osvrnuti na drugi stavak člankom 36. Obiteljskog zakona koji, naprotiv, propisuje kako dobitak od igara na sreću i imovinska korist od autorskoga prava i drugim pravima njemu srodnim ulaze u bračnu stečevinu. Znači da autorsko pravo ostaje vlastita imovina bračnog druga, dok eventualna imovinska korist koja proizlazi iz toga istog autorskog djela ulazi u bračnu stečevinu. Vezano za dobitak od igara na sreću, prilično je rijetko naići na normu kojom se ciljano ističu dobitci od igara na sreću kao kategorija dobara koja se ubraja u bračnu stečevinu. Zasigurno je ne nalazimo u talijanskom obiteljskom pravo, a rijetko bismo ju pronašli i u nekim drugim pravnim sustavima. Prema shvaćanju obiteljskopravne doktrine ubrajanje dobitaka od igara na sreću u bračnu stečevinu izraz je obiteljske solidarnosti, budući da je vrlo teško utvrditi podrijetlo novca s kojim je uplaćen sretan listić. No, postavlja se pitanje kako tumačiti suprotnu situaciju; onda kad umjesto dobitka nastane gubitak od igara na sreću. Nažalost ovo se doima mnogo češćim životnim primjerom u odnosu na dobitke od igara na sreću. Treba li se, analognim pravnim razmišljanjem, tumačiti da oba bračna druga solidarno odgovaraju za nastali dug? U nastavku će se rada analizirati odgovornost bračnih drugova za obveze prema trećima i pokušati odgovoriti na to.

Novouvedeni četvrti stavak članka 36. Obiteljskoga zakona glasi: „Uknjižba prava vlasništva na bračnoj stečevini koja je u naravi nekretnina može se provesti i na temelju prijedloga obaju bračnih drugova koji sadrži izričitu, pisanu i bezuvjetnu izjavu kojom jedan bračni drug pristaje na uknjižbu prava vlasništva drugoga bračnog druga u jednakim dijelovima ili drukčije ako su tako ugovorili“‘. Nadalje, peti stavak propisuje da navedena izjava mora biti ovjerena kod javnog bilježnika. Ovo je

20 Zakon o vlasništvu i drugim stvarnim pravima, NN, br. 91/1996, 68/1998, 137/1999, 22/2000, 73/2000, 129/2000, 114/2001., 79/2006., 141/2006., 146/2008., 38/2009., 153/2009., 143/2012., 152/2014. Više o svemu u: Belaj, V., Stjecanje imovine (vlasništva) u bračnoj i izvanbračnoj zajednici, Zbornik Pravnog fakulteta Sveučilišta u Rijeci, vol. 26, 1/2005, str. 346.; Klarić, P., Vedriš, M., Građansko pravo, Narodne novine, Zagreb, 2008., str. 247. Također v. Hrabar, D., Status imovine bračnih drugova - neka pitanja i dvojbe, Godišnjak 9, Aktualnosti hrvatskog zakonodavstva i pravne prakse, Organizator, Zagreb, 2002., str. 46.

21 Hrabar, D., Status imovine..., cit., str. 49. 
rješenje uvedeno Obiteljskim zakonom iz 2014., a zadržano je i u trenutačno važećem zakonu uz neke korekcije. ${ }^{22}$ Naime, u formulaciji spomenutog stavka u Obiteljskom zakonu iz 2014. stajalo je da „uknjižba prava vlasništva na bračnoj stečevini koja je u naravi nekretnina provodi se na temelju prijedloga obaju bračnih drugova koji sadrži izričitu, pisanu i bezuvjetnu izjavu (...)“; dok sadašnja norma umjesto „provodi se na temelju...“ glasi „može se provesti i na temelju“. Iz obrazloženja odredbi predloženog zakona iz 2014. pod novim člankom 36. glede četvrtog stavka može se pročitati kako se prema stavu pisca zakona tom odredbom nastoji „izbjeći pravna nesigurnost u prometu nekretnina“. Polazeći od načela povjerenja u zemljišne knjige, prema članku 8. Zakona o zemljišnim knjigama poštena treća osoba smatra istinitim ono što je upisano u zemljišne knjige. ${ }^{23}$ Prema obrazloženju odredbi tada predlaganoga zakona uvođenje ove odredbe s obiteljskopravne perspektive nalazi razlog u različitim stajalištima koja su se pojavila u sudskoj praksi, a opravdanost u cilju postizanja potpunog funkcioniranja načela povjerenja u zemljišne knjige kad je u pitanju imovina (nekretnine) koja ulazi u bračnu stečevinu..$^{24} \mathrm{U}$ obrazloženju odredbi predloženoga zakona, koje se nalazilo iza teksta konačnog prijedloga Obiteljskog zakona predstavljenog u 2014. godine stoji da: ,potrebno je pojednostaviti postupak uknjižbe prava vlasništva stečenog na temelju odredbe o bračnoj stečevini budući da Zakon o zemljišnim knjigama ne predviđa pojednostavljen način uknjižbe ovoga sui generis stečena prava vlasništva, pa bračni drugovi podliježu općim pravilima glede uknjižbe“.

Prema shvaćanju autorica, novouvedeni stavak 4. članka 36. propisuje da prijedlog uknjižbe oba bračna druga sadrži izjavu kojom jedan bračni drug pristaje na uknjižbu drugoga bračnog druga (klauzulu intabulandi). Iz gramatičkog tumačenja dalo bi se zaključiti da su to situacije kad bi isključivo jedan bračni bio upisan u zemljišnim knjigama, iako se radi o nekretnini koja je predmetom bračne stečevine. ${ }^{25}$

S time u vezi, valja spomenuti članak 37. Obiteljskoga zakona kojim se uređuje upravljanje bračnom stečevinom. Prvi stavak definira (premda ne taksativno) mogući primjeri redovitog upravljanja bračnom stečevinom te sadrži oborivu presumpciju

22 Obiteljski zakon, NN, br. 75/2014, 83/2014, 05/2015.

23 Zakon o zemljišnim knjigama, NN, br. 91/1996, 68/1998, 137/1999, 114/2001, 100/2004, 107/2007, 152/2008, 126/2010, 55/2013, 60/2013, 108/2017.

24 V. odluku Ustavnog suda Republike Hrvatske od 13. listopada 2004., posl. broj U-III-493/2002. (NN, br. 150/2004.), ali i odluku Ustavnog suda Republike Hrvatske od 14. lipnja 2011., posl. broj U-III-103/2008. Nadalje, odluku Vrhovnog suda od 23. travnja 1997., posl. broj Rev 2772/95 te odluku Vrhovnog suda od 19. listopada 2005., posl. br. Rev 142/2004. Recentno, v. odluku Vrhovnog suda Republike Hrvatske od 29. listopada 2013., posl. broj Rev 1867/12-2. Također, v. Županijski sud u Splitu, Gž Ob-97/16, od 15.IX.2016.; Županijski sud u Varaždinu, Gž Ovr-236/17-5, od 27.5.2017. U literaturi ex plurimis izdvajamo: Crnić, J., Končić, A., Utjecaj propisa o bračnoj stečevini te učincima izvanbračne zajednice na povjerenje u zemljišne knjige, Informator, br. 5487-5488, Zagreb, 7. i 11. listopada 2006., str. 1-9.; Kačer, H., (Izvan)bračna stečevina i zemljišne knjige - neka pitanja i dvojbe, Zbornik Pravnog fakulteta u Zagrebu, 55, 3-4/2005, str. 1037-1074.; Radolović, A., Načelo povjerenja (pouzdanja) u zemljišnu knjigu i raspolaganje bračnom stečevinom - kritički prikaz i analiza recentne prakse u Republici Hrvatskoj i Republici Sloveniji, Hrvatska pravna revija, 5/2005, str. 61-66.

25 Čl. 54. Zakona o zemljišnim knjigama. 
suglasnosti drugoga bračnog druga. Drugim stavkom zakonodavac nudi prilično iscrpan popis izvanrednih poslova za čije je poduzimanje potrebno zajedničko djelovanje ili pisana suglasnost s ovjerom potpisa kod javnog bilježnika bračnog druga koji ne sudjeluje u poslu. U trećem se stavku jasno propisuju posljedice nepostojanja suglasnosti i za poslove redovitog i izvanrednog upravljanja. U odnosu na poštene treće osobe, $u$ oba slučaja nepostojanje suglasnosti ne utječe na njihova prava $i$ obveze stečene sklapanjem pravnog posla s bračnim drugom. U odnosu na bračnog druga koji nije dao suglasnost, propisuje se mogućnost da on traži naknadu štete, ali samo ako su u pitanju izvanredni poslovi. U ranije tumačenom obrazloženju nisu pronađeni argumenti u smislu povezivanja ovih posljedica i novouvedene klauzule intabulandi. Ipak, držimo korisnim istaknuti da se kombiniranim čitanjem ovih odredaba Obiteljskog zakona može zaključiti da daju rješenje kojim se kompromisno rješava delikatno pitanje treba li prevagnuti zaštita poštenog trećeg, što je zasigurno odgovor koji prevladava iz građanskopravne perspektive ili treba prevagnuti prema obiteljskopravnom pristupu neupisani bračni drug. Kompromis kojeg čine s jedne strane mogućnost davanja izjave koja sadrži klauzulu intabulandi u korist drugoga bračnog druga, a s druge izričita zaštita poštenog trećeg na kojeg se ne odražavaju posljedice eventualno izvanrednog posla kojeg je poduze jedan bračni drug ultra vires, izražava se u tomu što ako se bračni drug ne upiše na temelju mogućnosti predviđene člankom 36., stavkom 4., kasnije ne može pobijati posao između drugoga bračnog druga i poštenog trećeg. Jedino što može tražiti jest naknadu štete od strane drugoga bračnog druga. Radi se o novini u zakonodavstvu koja dodatno unaprjeđuje uređenje imovinskih odnosa bračnih drugova, osobito kad je pitanje posljedica njihovog poduzimanja pravnih radnji s trećim osobama.

\subsection{Ugovorno uređenje imovinskih odnosa bračnih drugova}

Obiteljski zakonodavac dopušta bračnim drugovima mogućnost ugovornog uređenja međusobnih imovinskih odnosa. Predmet i način sklapanja bračnog ugovora, kao i pravni učinci u odnosu na treće osobe regulirani su člankom 40. Obiteljskoga zakona. Radi se o odredbi koja je po svom sadržaju ista od prvog Obiteljskog zakona iz 1998., kad se prvi put uvela mogućnost šireg ugovaranja imovinskih odnosa u braku, pa sve do trenutačno važećeg zakona. ${ }^{26}$ Premda je mogućnost ugovaranja različitog režima u odnosu na zakonski izraz afirmacije autonomije volje bračnih drugova, ipak se u društvu ta prilika rijetko koristi. Kao što se ističe u (domaćoj i inozemnoj) obiteljskopravnoj doktrini često se gleda na namjeru detaljnog reguliranja imovinske sfere međusobnih odnosa kao na nešto što se bitno kosi s romantičnom idejom braka. ${ }^{27}$ De facto, bračni drugovi ne sklapaju često bračne ugovore bilo iz razloga što nisu dovoljno informirani o načinima i mogućnostima uređenja međusobnih

26 Belaj, V., op. cit., str., 356; Korać Graovac, A., op. cit., 514. čl. 259., Obiteljski zakon, NN, br. 162/1998.; čl. 255. Obiteljskog zakona, NN, br. 116/2003., 17/2004., 136/2004., 107/2007., 57/2011., 61/2011., 25/2013., 05/2015.; čl. 40. Obiteljski zakon, NN, br. 75/2014., 83/2014., $05 / 2015$.

27 Loc. cit.; Patti, S., Cubeddu, M. G., Introduzione al diritto della famiglia in Europa, Milano, Giuffrè, 2008., str. 197. 
imovinskih interesa u braku, bilo iz razloga što misle da je zakonski režim primjeren zaštiti njihovih imovinskih interesa. ${ }^{28} \mathrm{Kad}$ bi se vodila evidencija bračnih ugovora, primjerice često zagovaranim, ali nikad ozbiljno razmatranim prijedlogom uvođenja registra, znalo bi se o kojem broju sklopljenih bračnih ugovora govorimo, a ujedno bi se trećima jamčila mogućnost upoznavanja sa strukturom imovinskih odnosa potencijalnih dužnika. ${ }^{29}$

Ipak, valja uzeti u obzir određene parametre koji bi mogli ukazati na porast broja bračnih ugovora u budućnosti. Ponajprije, treba uzeti u obzir da postoji određen broj građana s visokim prihodima koji zasigurno imaju interesa odstupiti od zakonskog režima koji, kao što se spominjalo, počiva na načelu obiteljske solidarnosti neovisno o realnom doprinosu u stvaranju bračne stečevine. Također bi valjalo uzeti u obzir da osobe ulaze u brak u sve zrelijim godinama, pa je utemeljeno zaključiti da bi mogle ozbiljnije razmišljati o reguliranju pitanja imovine. Zapravo ovaj se zaključak izvodi iz razmatranja talijanske doktrine koja ističe da, što su nevjesta i ženik stariji, to rjeđe biraju zakonski režim zajedničke imovine. ${ }^{30}$ Kao treće, za vjerovati je da će osobe koje ulaze u novi brak, ponukane ranijem iskustvom, drugi put ugovorno urediti međusobne imovinske interese. $U$ tom pogledu, ističe se u doktrini kako je sklapanje bračnih ugovora „postalo raširenije kao način uređenja imovinskih odnosa prije razvoda braka kod bračnih drugova koji su zadržali sposobnost komunikacije, kao način izbjegavanja sudskog spora o imovinskim odnosima". ${ }^{31}$

Prvi stavak članka 40. Obiteljskog zakona propisuje da se bračnim ugovorom mogu urediti imovinskopravni odnosi na postojećoj ili budućoj imovini. Što se tiče forme, prema trećem stavku istog članka, kako bi ugovor bio valjan potrebno ga je sklopiti u pisanom obliku, a potpisi bračnih drugova moraju biti ovjereni kod javnog bilježnika. S obzirom na to da predmet bračnog ugovora nije izričito određen, dalo bi se zaključiti da je svaki bračni ugovor koji se ne protivi prisilnim propisima dopušten. Naime, u doktrini se detaljno razrađuje pitanje prepoznavanja mogućega predmeta bračnog ugovora, odnosno definiranja osnovnog sadržaja ugovaranja u odnosu na bračnu stečevinu u cilju otklona zakonskog režima. ${ }^{32}$ Zatim se istražuje koja bi se stvarna i/ili obvezna prava mogla osnovati na tom ugovoru te koja se pitanja uređuju, a da se odnose na sam bračni ugovor (npr. određeni rok, uvjet, raskid...). ${ }^{33}$ Nemajući dovoljno prostora u ovom radu za dublje upoznavanje s bračnim ugovorom, za potrebe komparativne analize dvaju sustava, dovoljno je istaknuti da talijansko pravo ne dopušta bračnim drugovima mogućnost ugovornog uređenja imovinskih

28 Premda je matičar prema čl. 15., st. 5. Obiteljskog zakona dužan nevjestu i ženika upoznati s mogućnostima uređenja imovinskih odnosa prema Zakonu, teško je da su uoči sklapanja braka nevjesta i ženik na to fokusirani.

29 O mogućim načinima uvođenja registra bračnih ugovora detaljno su pisali: Čulo, A., Šimović, I., Registar bračnih ugovora kao doprinos sigurnosti u pravnom prometu, Zbornik Pravnog fakulteta u Zagrebu, god. 59, 5/2009, str. 1029-1068.

$30 \mathrm{U}$ tom pogledu, u Italiji bračni drugovi sve češće odabiru režim odvojenih imovina, koji je u talijanskom pravnom sustavu bio zakonski režim sve do reforme iz 1975. godine.

31 Doslovno citiramo: Korać Graovac, A., op, cit., str. 515.

32 Majstorović, I., Bračni ugovor: novina hrvatskog obiteljskog prava, Zagreb, Pravni fakultet u Zagrebu, 2005., str. 194 et seq.

33 Ibid., str. 201 et seq. 
odnosa nalik hrvatskom bračnom ugovoru kojeg možemo prema sadržaju kvalificirati kao atipičnim, budući da dopušta doista veliku slobodu ugovaranja, a svaka bračna zajednica bi mogla imati svoje razloge zašto urediti neke aspekte njihovih imovinskih odnosa baš na određeni način. ${ }^{34}$

Za potrebe ovog rada valja spomenuti članak 42. Obiteljskog zakona koji uvodi jedno (od rijetkih) ograničenja slobodi ugovaranja bračnih drugova. Preciznije, tom se odredbom zabranjuje bračnim drugovima ugovaranje primjene stranog prava pri uređenju njihovih imovinskih odnosa. Doktrina nalazi opravdanje ovoj zabrani u potrebi da bračni drugovi primjene svojim imovinskim odnosima propis nacionalnog zakonodavstva, odnosno onog sustava za kojeg se smatra da su najuže vezani. Pretpostavlja se da će bračni drugovi najbolje poznavati upravo domaće zakonodavstvo. Štoviše, ideja zakonodavca je ta da se izbjegne primjena stranog prava koje bi moglo biti manje povoljno za bračne drugove u odnosu na domaće. ${ }^{35}$

Radi se o zabrani koju se može nerijetko pronaći u europskim obiteljskim zakonodavstvima. Primjerice, nailazimo na istovjetnu odredbu u $§ 1409$. njemačkoga BGB-a, dok u članku 161. talijanskog codice civile stoji (nejasna) zabrana uređenja imovinskih odnosa „općenitom primjenom pravnih izvora koji se uobičajeno ne primjenjuju na bračne drugove“. To bi značilo da se može primijeniti strano pravo i kad se radi o talijanskim bračnim drugovima, ali je potrebno jasno navesti izvore i sadržaj. Doima se da različito od hrvatskoga zakonodavca, talijanski ne brine o tomu hoće li se primijeniti pravo koje najviše ide in favorem bračnim drugovima jer ga najbolje poznaju, već pravno rješenje koje i treće osobe, koje dolaze u doticaj s bračnim drugovima (kao dužnicima) i njihovom imovinom, poznaju ili bi mogle lako upoznati. To se izvodi iz tumačenja doktrine na temelju kojih se zaključuje da bračni drugovi, ako izaberu strano pravo moraju navesti točne izvore i odredbe u sporazumu. Radi se o liberalnijem rješenju, ali ne smijemo zaboraviti da talijanski bračni drugovi ne mogu istinski ugovorno urediti imovinske odnose. Stoga u već ograničenom prostoru izražavanja autonomije volje bračnih drugova nije bilo potrebe za dodatnim sužavanjem uvođenjem navedene zabrane.

U svim tim rješenjima prepoznajemo zajedničku ratio legis: jamčenje sustava uređenja imovinskih odnosa koji počiva na pravilima s kojima su bračni drugovi upoznati i kojima se također trećim osobama, koje dolaze u doticaj s imovinom bračnih drugova, jamči mogućnost ostvarivanja svojih prava i potraživanja. Uredbom 1103/2016, barem u dijelu koji se odnosi na bračnoimovinske režime koja imaju prekogranična obilježja doći će do promjena s obzirom na mogućnost odabira mjerodavnog prava. To će zasigurno dovesti do određenih teškoća s obzirom na već spomenuti nedostatak informiranosti bračnih drugova u pogledu uređenja $u$ nacionalnom zakonodavstvu, a kamoli u stranom. Štoviše, nedostatak ili nedostatnost publiciteta postojećih imovinskopravnih režima $u$ ponekim sustavima (poput hrvatskog i talijanskog) mogao bi izazvati probleme glede sposobnosti poštenih trećih

34 Vidi više u: Ivančić-Kačer, B., Klasiček, D., Bračni ugovor - neka otvorena pitanja, u: Hrabar, D. (ur.), Odabrane teme iz građanskog i obiteljskog prava, Zagreb, Pravni fakultet Sveučilišta u Zagrebu, 2008, str. 1-30.; Belaj, V., op. cit., str. 358.

35 Korać Graovac, A., op. cit., str. 517; Majstorović, op. cit., str. 215. 
osoba da znaju kojim su pravilima uređeni imovinski odnosi bračnih drugova s kojima sklapaju pravne poslove, odnosno koji postaju njihovi dužnici.

\subsection{Odgovornost bračnih drugova za obveze prema trećim osobama}

U svjetlu razmatranoga drži se potrebnim analizirati još jedan aspekt imovinskih odnosa bračnih drugova, koji se odnosi na njihovu odgovornost za obveze koje su preuzeli prema trećim osobama. S tim u vezi, Obiteljskim zakonom iz 2014. godine ponovno su uvedene odredbe koje je kasnije zadržao i Obiteljski zakon iz 2015. godine, a kojima se propisuje odgovornost bračnih drugova za obveze prema trećim osobama. Riječ je o člancima 43. i 44. Obiteljskog zakona koji se odnose na pojedinačne i na solidarne obveze bračnih drugova. U ovom će dijelu rada doktrina koja datira iz ranijih razdoblja uređenja obiteljskog prava poslužiti tumačenju „,novih“ odredaba. ${ }^{36}$ Naime, slične su odredbe postajale u prošlosti u razdoblju kad se primjenjivao Osnovni zakon o braku iz 1946. godine, kao i Zakon o braku i porodičnim odnosima iz 1978. godine. ${ }^{37}$

Štoviše, kao što proizlazi iz obrazloženja odredbi Obiteljskog zakona iz 2014. te iz provedenog istraživanja koji je prethodio pisanju ovog rada, istovjetna rješenja poznata su u poredbenom pravu. ${ }^{38}$ Osobito talijanska doktrina razvila je mnogobrojne teorije i ponudila raznovrsna tumačenja koja de facto ukazuju na složenost i slojevitost ovog pitanja, a ta će kompleksnost samo rasti stupanjem na snagu Uredbe br. 1103/2016. To i jest razlog što smo odabrali taj strani pravni sustav. Tamošnja plodna znanstvena rasprava mogla bi potaknuti daljnji razvoj ove materije i u tuzemnom pravu.

Prvi članak kojim se uređuje pitanje odgovornosti bračnih drugova za obveze prema trećima je članak 43. Obiteljskog zakona. Napose, propisano je da za obveze koje je jedan bračni drug imao prije sklapanja braka, taj bračni drug odgovara pojedinačno. Nadalje, odgovara pojedinačno i za obveze koje je preuzeo nakon sklapanja braka, ako se ne odnose na tekuće potrebe bračne i obiteljske zajednice. Drugim riječima, u navedenim situacijama drugi bračni drug ne odgovara. Postoji samo jedan dužnik od kojeg će treći vjerovnik tražiti ispunjenje obveze i koji će

36 Bakarić-Abramović, A., Hrabar, D., Imovinski odnosi, Alinčić, M. i dr., Obiteljsko pravo, Zagreb, Birotehnika CDO, 1994., str. 391; Alinčić, M., Bakarić, A., Porodično pravo, 3. izd., Zagreb, Narodne novine, 1989., str. 320; Alinčić, M., Bakarić-Mihanović, A., Porodično pravo, Zagreb, 1980., str. 361; Prokop, A., op. cit., str. 49.

37 Članak 11. Osnovnog zakona o braku iz 1946. godine, glasio je: "Za obveze, koje je jedan bračni drug imao prije stupanja u brak, kao i za obveze, koje primi poslije stupanja u brak, ne odgovara drugi bračni drug". Nadalje, drugi je stavak glasio "Za obveze, koje u toku braka uzme na sebe jedan bračni drug za tekuće potrebe zajednice, odgovara vjerovnicima i drugi bračni drug kao da ih je on sam na sebe uzeo". Dok je čl. 288. Zakona o braku i porodičnim odnosima iz 1978. godine glasio: "Za obveze koje je jedan bračni drug imao prije stupanja u brak kao i za obveze koje je samostalno preuzeo poslije stupanja u brak ne odgovara drugi bračni drug". Nadalje drugi stavak: "Za obveze iz stava 1, ovog člana bračni drug odgovara svojom posebnom imovinom i svojim udjelom u zajedničkoj imovini”. Stavak 3.: "Zahtjev za utvrđivanje dijela bračnog druga u zajedničkoj imovini može postaviti i vjerovnik bračnog druga".

38 Osim talijanskoga pravnog sustava, slična pravna rješenja nude § 96. austrijskog ABGB-a i $\S$ 1357. njemačkog BGB-a. 
odgovarati svojom imovinom.

Nasuprot tomu, člankom 44. uređuje se solidarna odgovornost bračnih drugova. Prvi stavak glasi: ,za obveze koje je jedan bračni drug preuzeo radi namirenja tekućih potreba bračne i obiteljske zajednice, kao i za obveze koje su bračni drugovi preuzeli zajednički u vezi s bračnom stečevinom, odgovaraju oba bračna druga solidarno bračnom stečevinom i vlastitom imovinom. "Drugim stavkom propisano je pravo jednoga bračnog druga na regres u odnosu na drugoga bračnog druga ako je naplaćeno više nego što iznosi njegov dio duga. Konačno, trećim je stavkom postavljena oboriva presumpcija o odgovornosti bračnih drugova u jednakim dijelovima, što je logično predmnijevati s obzirom na presumpciju o suvlasništvu u bračnoj stečevini. Da se radi o oborivoj presumpciji čini se opravdanim s obzirom na to da bračni drugovi mogu ugovorno drukčije urediti međusobne imovinske interese. Nameću se razna pitanja vezana za tumačenje ove odredbe. U prvom redu, valja se osvrnuti na pojam „tekućih potreba bračne i obiteljske zajednice“. Uobičajeno je ubrajati među tekuće potrebe one koje se ponavljaju (npr. režije), ali mogu biti i potrebe koje se javljaju jednokratno. ${ }^{39}$ Ipak, valja naglasiti da prema tumačenju doktrine pojam ,tekućih“ potreba varira shodno ekonomskim i drugim prilikama bračnih drugova. S time u vezi, prof. Prokop isticala je kako kvalifikacija istih ovisi o subjektivnom kriteriju koji varira shodno ekonomskim prilikama koje kvalificiramo pojmom životni standard. Time se ističe da nije nužno rečeno da se za svaku obitelj mogu raspoznati iste ,tekuće potrebe“. Stoga možemo zaključiti da ako je određena obveza nerazmjerno velika u odnosu na životni standard obitelji, mogla bi predstavljati pojedinačnu obvezu bračnog druga, pa time biti podložna primjeni članka 43ako ju bračni drugovi nisu zajednički preuzeli. Postavlja se i dodatno pitanje razlike između tekućih potreba bračne zajednice i potreba obitelji. Ako postoji obitelj, odnosno kad su prisutna djeca, mogu li tekuće potrebe bračne zajednice, tumačeći taj pojam na način da isključuje potrebe djece, prevagnuti nad potrebama djece? Nije se naišlo u ovom istraživanju na sudsku praksu u tom pogledu, no zanimljivo je istaknuti da je to pitanje itekako prisutno u talijanskom pravu, dajući naslutiti da eventualne obveze preuzete u cilju (sebičnog) zadovoljavanja potreba bračnih drugova ne mogu se kvalificirati kao obveze za koje bračni drugovi odgovaraju i bračnom stečevinom. Naime, polazeći od postulata zaštite najboljeg interesa djeteta, talijanska doktrina afirmira da takve obveze ne mogu teretiti imovinu koja ulazi u bračnu stečevinu, koja s obzirom na afirmaciju načela solidarnosti u obitelji služi u prvom redu zadovoljavanju potreba djece (npr. školovanje i obrazovanje). Ipak, u tom pogledu, drži se da je inozemno tumačenje prilično strogo i teško primjenjivo u tuzemnom pravnom sustavu jer postoji jedna bitna razlika u pojmovima koji se koriste u hrvatskom i talijanskom zakonodavstvu. Za razliku od domaćeg obiteljskog prava, talijansko koristi pojam ,interesa“ umjesto „potreba“, što uvelike otvara mogućnost i zadovoljavanju određenih potreba koje se teško mogu povezati s normalnim „funkcioniranjem“ bračne/obiteljske rutine.

U svakom slučaju, ne bi bilo zgorega detaljnije definirati ovaj pojam. Primjerice,

39 Prema obrazloženju odredbi uoči donošenja Obiteljskog zakona iz 2014. godine takve bi tekuće potrebe mogle biti, primjerice najam stana, nabavka hrane, odjeće ili obuće za članove obitelji, troškovi popravaka kućanskih aparata ili namještaja, troškovi liječenja itd. 
što ako za zadovoljavanje tekućih potreba bračni drugovi posegnu za nenamjenskim kreditnim sredstvima, a kasnije se ta sredstva rasipnu za druge potrebe koje ne ulaze po definiciji u one tekuće bračne i/ili obiteljske? Ranije se govorilo o dobitcima od igara na sreću kao imovini koja ulazi u bračnu stečevinu: što s gubitcima? Pitanje je mogu li se smatrati dugovi za koja solidarno odgovaraju bračni drugovi, a sklonost je autorica tumačiti ih kao obveze koje in re ipsa nemaju obilježja iz članka 44. Obiteljskoga zakona. Iz prve se promišljalo pronaći opravdanje isključivanja u njihovu aleatornom karakteru; no, to nije dovoljno. Postoje aleatorni ugovori, poput ugovora o osiguranju koji se mogu sklopiti zbog opasnosti da se pojavi određeni štetni događaj. Njime se de facto štiti bračna stečevina (npr. osiguranje nekretnine). U tim je slučajevima preuzimanje rizika opravdano, dok kod igara na sreću nedostaje opravdanost preuzimanja rizika.

U nastavku prvog stavka, članak 44. spominje obveze koje su bračni drugovi preuzeli „zajednički u vezi s bračnom stečevinom“. Kad bi se tim izrazom mislilo na isto što i s „tekućim potrebama“ ne bi postojao razlog za ponavljanje. Razvidno je kako se pojmom obveza preuzetih zajednički u vezi s bračnom stečevinom gubi ideja „tekućih potreba“. Naprotiv, ide se u smjeru preuzimanja obveza koje mogu znatno više opteretiti imovinu bračnih drugova, a koje se odnose na poslove redovite ili čak izvanredne uprave bračne stečevine. U tim je obvezama bitno to što su preuzete zajednički. No, tu bi se moglo opetovano razmotriti pitanje njihove kvalifikacije. Presumira li nužno činjenica da je obveza preuzeta zajednički i njezinu povezanost s ostvarivanjem ekonomske funkcije bračne zajednice?

Možda je ipak dijelom nepotrebno postavljati ovo pitanje s obzirom na to da domaći obiteljski zakonodavac ne propisuje redoslijed kojim će se treći vjerovnici naplatiti na imovini bračnih drugova. U predmetnoj odredbi stoji isključivo da bračni drugovi odgovaraju bračnom stečevinom i vlastitom imovinom. Razmišljajući o razlozima postojanja imovinskog režima kojeg poznajemo, a koji počiva na načelu obiteljske solidarnosti možda bi se tu moglo pronaći prostora za daljnje unaprjeđenje obiteljskog zakonodavstva. ${ }^{40} \mathrm{~S}$ druge pak strane, svjesni smo temeljne kritike koja bi se mogla uputiti prijedlogu uvođenja redoslijeda, a koja bi se odnosila na to da bi to značilo zahtijevati od trećeg vjerovnika da prije negoli se upusti u pravni posao $\mathrm{s}$ dužnikom provjeri njegovo bračno stanje, odnosno mogućnost naplate iz određene kategorije dobara kojima raspolaže bračni drug. To bi značilo da bi treća osoba/ vjerovnik trebao moći znati unaprijed kako je određeni subjekt uredio svoju imovinsku sferu, što bi značilo zahtijevati preveliki angažman. A to bi bilo uistinu tako, osim kad bi se osvijestio i riješio drugi problem vezan za imovinske režime bračnih drugova, a to jest nedostatak adekvatnog publiciteta tih režima.

40 Obiteljskopravna doktrina, ističući nedostatak normiranja redoslijeda namirenja, podsjeća na postojeće „korekcije“ propisane Ovršni zakonom, Korać Graovac, A., op. cit., str. 522. 


\section{IMOVINSKI ODNOSI BRAČNIH DRUGOVA U TALIJANSKOM OBITELJSKOM PRAVU}

Talijanski građanski zakonik (codice civile) člankom 143. propisuje obvezu oba bračna druga, u skladu s njegovim/njezinim mogućnostima i sposobnošću za rad u profesionalnom okruženju i u domaćinstvu, pridonošenja potrebama obitelji. Obveza pridonošenja (tal. dovere di contribuzione) jedan je od stupova talijanskog obiteljskog prava ili, bolje rečeno, mostova s obzirom da povezuje osobne i imovinske aspekte obiteljskopravnih odnosa. ${ }^{41}$ Kako bi bračni drugovi mogli istinski ostvariti zajednicu života mimo koje pojam obitelji gubi smisao, potrebno je tu bračnu zajednicu prikladno urediti i u kontekstu osobnih i imovinskih interesa. U talijanskoj se literaturi često ističe da su imovinski odnosi osnovni instrument rješavanja egzistencijalnih pitanja među članovima obitelji. Potreba zaštite tih pitanja može se iščitati iz mnogobrojnih odredaba talijanskog Ustava, koje ih postavljaju u sam vrh hijerarhije vrijednosti, premda balansirajući ih s ostalim ustavnopravnim vrijednostima, poput zaštite prava privatnog vlasništva i slobode poduzimanja gospodarske inicijative. Stoga, tumačeći odredbe codice civilea u svjetlu temeljnih talijanskih ustavnih vrijednosti, može se tvrditi da obveza pridonošenja potrebama obitelji ima karakter stroge norme koju bračni drugovi moraju poštovati. Ergo, prema talijanskom obiteljskom pravu bračni drugovi dužni su materijalno doprinijeti potrebama obitelji u cilju uzajamnog pomaganja te skrbi o djeci. Napose, ta je obveza primarnoga karaktera. U talijanskom pravu ona odražava tzv. primarni režim imovinskih odnosa u obitelji (tal. regime patrimoniale primario della famiglia). To znači da istovjetna obveza postoji u svim različitim režimima među kojima talijanski bračni drugovi mogu birati, a to su: zakonski režim zajedničke stečevine (zajednice imovine - comunione dei beni), alternativni režim ugovorene stečevine i alternativni režim odvojenih imovina.

Zakon br. 76. iz 2016., koji je tek nedavno prvi put pravno uredio civilne zajednice (tal. unioni civili) među osobama istoga spola i zajednice osoba različitoga spola izričito propisuje obvezu pridonošenja potrebama obitelji i u slučaju postojanja zajednica različitih od bračne, i to člankom 1., stavak 11. u slučaju civilnih zajednica te stavcima 36. i 53., slovo b) istoga članka kad su u pitanju (neformalni) odnosi kohabitacije. ${ }^{42}$ Štoviše, člankom 1., stavak 57., slovo b), propisana je ništetnost ugovora o kohabitaciji sklopljenog protivno obvezi pridonošenja potrebama obitelji. Time talijanski zakonodavac afirmira ranije spomenute ustavnopravne vrijednosti kojima se primarno poštuje egzistencijalna sfera svakoga čovjeka. Naime, bilo koji oblik ostvarivanja obiteljskog života, koji počiva na tzv. affectio coniugalis i na ostvarenju zajedničkog života, u talijanskom obiteljskom pravu počiva na imovinskopravnim rješenjima koja moraju biti usklađena s primarnom obvezom pridonošenja potrebama obitelji. Nedavno, pri još jednoj važnoj reformi obiteljskoga prava, koja se ticala odnosa roditelja i djece, 2013. godine važnost obveza pridonošenja potrebama obitelji

41 U tom pogledu v. Perlingieri, P., Manuale di diritto civile, Napoli, Edizioni Scientifiche Italiane, 2018., str. 1036.

42 O novim zakonskim rješenjima više u: Perlingieri, G., Interferenze tra unione civile e matrimonio. Pluralismo familiare e unitarietà dei valori normativi, Rassegna di diritto civile, 1/2018., str. 101. 
proširena je i na dijete koje živi u obitelji. Talijanski je zakonodavac time želio istaknuti da svi članovi obitelji koji žive u životnoj zajednici imaju aktivnu ulogu u toj uzajamnoj obvezi brige jedni za druge koja se u talijanskom pravu naziva obvezom pridonošenja potrebama obitelji. Drugim riječima članovi obitelji, u skladu s njihovim mogućnostima, dužni su brinuti o potrebama cjelokupne obitelji.

Iz svega do sada izloženog proizlazi jasna i snažna povezanost koja u talijanskom obiteljskom zakonodavstvu postoji između pravnog uređenja imovinskih odnosa i načela solidarnosti iz članka 2. talijanskog Ustava. Radi razumijevanja čitave pravne strukture koja se temelji na obvezi pridonošenja potreba obitelji prijeko je potrebno kombinirano čitati članke 143. i 144. talijanskog codice civilea. Napose, valja naglasiti da kad se obveza pridonošenja potrebama obitelji odnosi na bračne drugove ona obilježava i konkretnu primjenu načela jednakosti među bračnim drugova. Ustavno načelo jednakosti još je jedno načelo na kojem počivaju mnogobrojne odredbe talijanskoga obiteljskog prava, osobito nakon velike reforme zakonodavstva 1975. godine. Na jednakosti među bračnim drugovima počiva ratio članka 144. codice civilea, kojim se definira kako je usmjerenje obiteljskog života plod dogovora bračnih drugova, neovisno o pojedinačnoj sposobnosti i visini privređivanja materijalnih sredstava bračnog druga te neovisno o odabranom imovinskopravnom režimu u obitelji.

Nakon što se ukratko pojasnilo na kojim se pravnim načelima temelji uređenje imovinskih odnosa $u$ talijanskom obiteljskom pravu te konstatiralo da se radi o istovjetnim vrijednostima ranije prepoznatima u hrvatskom obiteljskom pravu, potrebno se usredotočiti na predmet ovog istraživanja. Fokus ovog rada proučavanje je imovinskih režima i odnosa bračnih drugova prema trećim vjerovnicima uz sva kompleksna pitanja koja nastaju osobito vezano za kvalifikacije obveznih odnosa koji su sklopljeni radi ostvarivanja obiteljskih interesa, za utvrđivanje solidarne odgovornosti bračnih drugova, imovine kojom odgovaraju i kojim redoslijedom, pitanja provođenja prisilne naplate te pitanja posljedica stupanja na snagu Uredbe br. 1103 iz 2016. u odnosu na postojeći pravni sustav.

Postoji čitavi normativni korpus (članci od 186. do 190. codice civilea) posvećen vanjskom utjecaju imovinskog režima zajedničke stečevine u odnosu na treće osobe. Valja naglasiti da je režim zajedničke stečevine u Italiji zakonski režim, koji se automatski primjenjuje na sve bračne drugove, osim ako nisu izričito odabrali jedan od alternativnih režima uređenja njihovih imovinskih interesa. Već se ranije spominjalo da alternativni režimi propisani talijanskim obiteljskim pravom su režim odvojene imovine ili ugovorene stečevine. Talijanski je zakonodavac tim odredbama (članci od 186. do 190.) propisao pravila uređenja posljedica koje potječu iz obveznog odnosa nastalog između bračnih drugova i trećih osoba i to normirajući rješenja i onda kad bračni drugovi odgovaraju zajedničkom imovinom i onda kad odgovaraju vlastitom imovinom zavisno o osnovi nastaje obveznopravno potraživanje. ${ }^{43}$ Naime, propisana su rješenja vrlo detaljna, ali i složena, budući da se s njima nastoji jamčiti ravnoteža

43 Složenim aspektom odnosa između uređenja bračne stečevine i trgovačkog prava bavi se Trimarchi, G. A. M., Le imprese dei coniugi, u: Perlingieri, P. (ed.), Trattato di Diritto Civile del Consiglio Nazionale del Notariato, Napoli, Edizioni Scientifiche Italiane, 2015., str. 13. 
između slobode ugovaranja bračnog druga s jedne strane te načela solidarnosti i jednakosti, s druge. ${ }^{44}$

Pri tumačenju tog normativnog korpusa koji regulira pitanja odgovornosti bračnih drugova u odnosu na treće osobe uočava se kao osnovni problem poteškoća u povezivanju pravila uređenja zakonskog režima imovinskih odnosa u braku s načelima poput nedodirljivosti imovinske sfere pojedinaca, relativnosti posljedica sklapanja ugovora te opće nedopustivosti postojanja sustava odgovornosti bez duga. U tom pogledu talijanska sudska praksa doista je opsežna i često nekoherentna. Stoga, pri tumačenju ovih odredbi kroz desetljeća se pokušavalo pronaći rješenja u talijanskoj sudskoj praksi kojima se uklanja legitimacija jednoga bračnog druga u obvezivanju drugoga (i posljedično njegove imovine) ili kojima se jednom bračnom drugu dopušta zastupanje drugoga. Zasigurno jedna od najvažnijih sudskih odluka po tom pitanju je presuda talijanskog Kasacijskog suda br. 6118 iz 1990., godine prema kojoj, iako je obveza nastala u cilju ostvarivanja određenog interesa obitelji, da bi jedan bračni drug obvezao i drugoga, potrebne je da se trećoj osobi stvori čvrsto uvjerenje da se jedan bračni drug obvezao i u ime drugoga, rectius da se i taj drugi bračni drug htio obvezati. ${ }^{45}$

Solidarna odgovornost bračnih drugova kad su u pitanju obveze nastale $\mathrm{u}$ interesu obitelji i solidarna odgovornost iz obveznog prava uređene su istim zakonikom (codice civile). Međutim u talijanskoj doktrini i u sudskoj praksi uvriježeno je tumačenje prema kojem se radi o različitim institutima, koji se nalaze u odnosu species i genus. Razlog tomu jest pekulijarnost obiteljskih imovinskih odnosa koji zahtijevaju specifična imovinskopravna rješenja. No, to ne mogu biti opća rješenja predviđena u obveznom pravu, koja se primjenjuju na bilo koji obveznopravni odnos između dužnika i vjerovnika. Napose, dok u solidarnim obvezama subjekt koji ispuni tražbinu u cijelosti ima pravo regresa prema sudužniku za polovicu duga, bračni drug koji, primjerice plati u cijelosti ima također pravo regresa prema sudužniku, odnosno njegovu bračnom drugu, ali ne za polovicu duga, već za iznos predviđen člankom 143. stavak 3. codice civilea. Naime, u odnosima među bračnim drugovima za obveze nastale radi zadovoljavanja potreba obitelji, dug mora biti razmjerno raspoređen shodno obvezi pridonošenja bračnoga druga, a to ne znači nužno na paritetan način. Drugim riječima, u talijanskom rješenju ne postoji presumpcija nalik onoj kojom se u hrvatskom zakonodavstvu predmnijeva da su bračni drugovi suvlasnici bračne stečevine u jednakim dijelovima. Stoga talijanska sudska praksa najviše instancije, počevši od presude br. 5487 iz 1999. godine, kontinuirano ističe da solidarna obveza koja nastaje u kontekstu bračnih odnosa nema i ne može imati ista obilježja solidarne obveze koju uređuje codice civile u dijelu posvećenom obveznopravnim odnosima. ${ }^{46}$

Spominjalo se ranije kako zakonski režim imovinskih odnosa u talijanskom pravu, tzv. režim zajedničke stečevine (tal. comunione degli acquisti) maksimalno poštuje načela jednakosti i solidarnosti. Međutim, talijansko obiteljsko zakonodavstvo

44 U tom pogledu, v. Oberto, G., I contratti della crisi coniugale, l'autonomia negoziale nei rapporti patrimoniali tra coniugi (non in crisi), Familia, 2003., str. 617.

45 Radi se o presudi Kasacijskog suda, 18. lipnja 1990., br. 6118, u: Corriere Giuridico, 1990., str. 1125, s osvrtom Carbone, V.

46 V. Ujedinjena vijeća Kasacijskog suda, 4. lipnja 1999., br. 5487, Notariato, 1999., str. 508. 
dopušta nupturijentima, odnosno bračnim drugovima mogućnost izbora različitog režima. Posebnim sporazumom bračni drugovi mogu izmijeniti režim zajedničke stečevine pod uvjetom da ne derogiraju odredbama koje se odnose na upravljanje dobrima koja ulaze u zajedničku stečevinu i na jednakost u odnosu na dobra koja bi činila zajedničku stečevinu ili na dobra koja se ne mogu ubrajati u zajedničku stečevinu (stvari strogo osobne prirode bračnoga druga, stvari koje služe poslovanju jednoga bračnog druga ili dobra koja su stečena na osnovi naknade štete ili ostvarene mirovine zbog djelomičnog ili potpunog gubitka sposobnosti za rad - članak 210 . codice civilea). stoga je moguće proširiti predmet zajedničke stečevine, uključivši u nju određenu vlastitu imovinu, prihode iz te vlastite imovine te plodove koji proizlaze iz odvojene djelatnosti, koji bi inače ušli u tzv. rezidualnu stečevinu i to samo eventualno i u trenutku prestanka imovinskoga režima (tal. comunione de residuo).

No, talijanski zakonodavac propisuje pravna rješenja kojima se uređuju odnosi bračnih drugova kao dužnika, odnosno sudužnika, i trećeg kao vjerovnika i u slučaju odabira režima, tzv. ugovorene stečevine (tal. comunione convenzionale). Naime, $\mathrm{u}$ talijanskoj doktrini i sudskoj praksi nedvojbeno je da će se primijeniti actio pauliana iz članka 2901. codice civilea svaki put kada vlastita imovina koja ulazi u, tzv. ugovorenu stečevinu prejudicira prava trećeg vjerovnika.

Isto tako, kad bračni drugovi odaberu režim odvojenih imovina, odnosno onda kad svatko nastavlja biti isključivi titular prava, korisnik i upravitelj nad imovinom stečenom i nakon braka, postoje određena dvojbena pitanja vezana za odnose prema trećim vjerovnicima. S tim u vezi, prema članku 219. codice civilea predmnijeva se da imovina pripada bračnim drugovima, osim ako se ne može dokazati da jedan bračni drug ima isključivo vlasništvo nad određenom dobru. To znači da postoji presumpcija postojanja zakonskog režima zajedničke stečevine. U tom slučaju prema članku 2725. codice civilea potrebno je dokazati isključivo vlasništvo dokumentiranim dokazom svaki put kad je za valjanost pravnog posla potrebna pisana forma. Presumpcija zajedničke stečevine odnosi se isključivo na bračne drugove i ne djeluje na štetu trećih. ${ }^{47}$ Postoji još jedan sporazum koji dijelom mijenja sustav zakonskog imovinskog režima u talijanskom bračnom pravu: imovinski fond (fondo patrimoniale). Radi se o akcesornom, a ne alternativnom režimu. Na temelju članka 167. c.c. svaki bračni drug (ili oboje) javnobilježničkim aktom ili treća osoba, i oporučno, može izdvojiti imovinu u cilju skrbi o potrebama obitelji. Mogu biti predmetom imovinskog fonda nekretnine, registrirane pokretnine i određeni vrijednosni papiri. Na temelju načela jednakosti pravo vlasništva pripada roditeljima osim ako se pri konstituiranju fonda ne odredi drukčije. Imovinski fond također je problematičan institut kada je u pitanju odnos prema trećim vjerovnicima. Specifična namjena koju dobiva imovina pri „ulasku“ $u$ fond onemogućava trećim vjerovnicima, koji imaju saznanje da određeni dugovi nisu nastali radi zadovoljavanja određenih interesa obitelji, pokretanje ovršnog postupka. Ipak, uvrštavanje dobara u imovinski fond radi njihovog izdvajanja, odnosno isključivanja, iz ovršive imovine može biti osnova za pokretanje tužbe prema članku 2901 c.c. (actio pauliana).

47 S tim u vezi upućuje se za daljnja razmatranja na članak 621. talijanskog Zakonika o parničnom postupku. 
Prima facie zaključilo bi se da zakonski režim (tal. comunione legale) je najčešći imovinski režim u talijanskom pravnom sustavu. Međutim nije nužno rečeno da je isti i najučinkovitiji sustav uređenja imovinskih interesa u bračnom pravu. Premda je ovaj presjek istaknuo tek osnovne razlike između pojedinačnih postojećih alternativa $\mathrm{u}$ talijanskom obiteljskom pravu, odmah se doima razvidnim, posebno domaćim pravnicima, kako analizirani susjedni pravni model ne poznaje mogućnost ugovornog uređenja imovinskih interesa u obitelji. Na prvi pogled, s obzirom na to da i talijansko zakonodavstvo spominje „sporazum“ i mogućnost „odabira“ alternativnog modela, reklo bi se da na isti način, kao i hrvatsko obiteljsko pravo dopušta normama dispozitivnoga karaktera drukčije uređenje imovinski interesa. Međutim, postoje znatne razlike između dva sustava. U hrvatskom je pravu moguće ugovorom urediti imovinske odnose i time se misli na onaj način koji je već ranije detaljno pojašnjen. U talijanskom pravu, sloboda ugovaranja je prilično ograničena. Moglo bi se zaključiti da autonomija volje ima prilično definiranje konture, odnosno da je sloboda ograničena na pravo izbora između alternativnih modela, koji su svi tipiziranog tipa. Nije predviđena bilo kakva mogućnost ugovaranja atipičnog bračnog ugovora. Uostalom nije slučajnost da se i u komparativnom obiteljskom pravu često koriste dva izraza koji nisu sinonimi, pa tako niti u ovom kontekstu: sporazum i ugovor. ${ }^{48} \mathrm{U}$ talijanskoj doktrini počinje se sve više promišljati o mogućnosti uvođenja atipičnih ugovora. ${ }^{49}$

Stupanjem na snagu Uredbe Vijeća (EU) 2016/1103 od 24. lipnja 2016. o provedbi pojačane suradnje u području nadležnosti, mjerodavnog prava te priznavanja i izvršenja odluka u stvarima bračnoimovinskih režima potreba za reformiranje tog dijela talijanskog obiteljskog prava nametnut će se još jače. Naime, Uredba, koja je donesena u postupku pojačanje suradnje i primjenjivat će se u osamnaest država članica Europske unije među kojima se nalaze Republika Hrvatska i Republika Italija, ističe se upravo radi svog otvorenog pristupa glede mogućih sporazuma koji se odnose na izbor nadležnog suda i mjerodavnog prava u svim situacijama kada postoji prekogranična implikacija u toj bračnoj zajednici, primjerice jer su bračni drugovi iz različitih država članica. ${ }^{50} \mathrm{U}$ preambuli br. 47 , Uredba definira da ,pravila o materijalnih i formalnoj valjanosti sporazuma o izboru mjerodavnog prava trebala bi se odrediti tako da se olakša informirani izbor bračnih drugova i da se poštuje njihov pristanak radi pravne sigurnosti, kao i lakšeg pristupa pravosuđu“. Stoga se očekuje da će se primjenom Uredbe će se neminovno ponovno pokrenuti rasprava već

48 Patti, S., Cubeddu, M. G., op. cit., str. 200.

49 S tim u vezi, Santosuosso, F., Delle persone e della famiglia. Il regime patrimoniale della famiglia, Comm. Cod. civ., I, 1, Torino, 1983., str. 331; De Rubertis, G., La comunione convenzionale tra coniugi, Riv. Notariato, 1989., str. 38; Grasso, B., La comunione convenzionale, Trattato Rescigno, 3, Torino, 1996., str. 645, kao i Confortini, M., La comunione convenzionale tra coniugi, Il diritto di famiglia, u: Trattato Bonilini-Cattaneo, II, Torino, 2007., str. 333.

50 Preciznije: Belgija, Bugarska, Češka, Njemačka, Grčka, Španjolska, Francuska, Hrvatska, Italija, Luksembourg, Malta, Nizozemska, Austrija, Portugal, Slovenija, Finska, Švedska i Cipar. Usp. Lagarde, P., Règlements 2016/1103 et 1104 du 24 juin 2016 sur les régimes matrimoniaux et sur le régime patrimonial des partenariats enregistrés, Rivista di diritto internazionale privato e processuale, 2016., str. 680 . 
i ranije poznata u talijanskoj doktrini i sudskoj praksi o stvarnoj ulozi autonomije volje pojedinaca u obiteljskopravnim imovinskim odnosima i da će se opet aktualizirati pitanje reformiranja talijanskoga obiteljskog prava o tomu. Ta se reforma, uistinu, odgađa već dugi niz godina, a naslućuje se da bi sada mogao biti trenutak za dugo iščekivane izmjene.

Valja istaknuti da se u talijanskoj doktrini jasno ističe kako pravila međunarodnoga privatnog prava temelje zaštitu trećih koji ulaze u obveznopravni odnos s bračnim drugovima na "načelu poznavanja“.$^{51}$ Naime, nesporno je u talijanskom pravu da se bračni imovinskopravni režim uređen inozemnim pravom može oponirati trećima isključivo ako su treći bili s njime upoznati ili ga nisu poznavali njihovom krivnjom. Očito je da će stupanje na snagu Uredbe postaviti nove prohtjeve glede poštovanja načela pravne sigurnosti te lakšeg pristupa pravosuđu, budući da se može ostvariti samo uz rastuću svijest o prednostima i nedostataka pravnih rješenja u kontekstu obiteljskog imovinskog prava pojedinačnih država članica, koje bi bračni drugovi mogli izabrati prema Uredbi te bolje poznavanje od strane vjerovnika zakonodavstva i unutar istog režima kojeg su bračni drugovi izabrali, a da nije ono nacionalno. ${ }^{52}$ Sustav nalik talijanskom, odnosno način na koji se daje publicitet imovinskim režimima, a tu bi se mogao spomenuti na isti način i hrvatski sustav, zacijelo nije dostatan ni prikladan poboljšanju poznavanja, što je jedan od prioriteta europskoga zakonodavstva.

\subsection{Zakonski režim zajedničke stečevine}

Zajednička je stečevina od svog uvođenja predmetom mnogobrojnih rasprava. Postavlja se još i danas pitanje koja je njezina ratio. O tomu doktrina nudi raznovrsne odgovore. Prema mišljenju nekih autora bit ovog pravnog instituta jest priznati materijalnu vrijednost ženskom radu u domaćinstvu. Prema mišljenju nekih drugih ovaj je institut izraz načela jednakosti među bračnim drugovima. Treća skupina autora smatra da ovo pravno rješenje izražava prihvaćanje određenog društvenog obrasca koji rezultira spajanjem u zajedničku stečevinu svega što su bračni drugi stekli tijekom braka.

Također nije jasna kvalifikacija pravne prirode ovog instituta. Mnogi autori pokušavaju tumačiti zajedničku stečevinu uspoređujući ju sa suvlasništvom i klasičnim stvarnopravnim odnosima, ističući da iz prve proizlaze obveznopravne posljedice, dok tek naknadno nastaju stvarnopravne posljedice. Na tragu ovog tumačenja instituta zajedničke stečevine, pravo bi vlasništva pripadalo onom bračnom drugu koji je poduzeo pravni posao kojim je stečeno pravo, dok bi drugi bračni drug imao (tek) pravo na ispunjenje tražbine drugoga bračnog druga, odnosno na plaćanje

51 Cubeddu, M. G., La pubblicità del regime dei beni e la scelta della legge applicabile, Famiglia, Persone, 2008., str. 710.

52 Članak 26., st. 3. Uredbe 1103/2016 propisuje primjenu prava različite države u odnosu na mjerodavno pravo prema prvom stavku, onda kad "oba su se bračna druga oslanjala na pravo te druge države u uređivanju ili planiranju svojih imovinskih odnosa”. Više u: Bruno, P., Le controversie familiari nell'Unione Europea. Regole, fattispecie, risposte, Milano, Giuffrè, 2018., str. 211. 
iznosa koji odgovara vrijednosti stvari. ${ }^{53}$ Takvo tumačenje počiva na interpretaciji odredaba iz članka 184. i 189. codice civilea. Preciznije, u slučaju nepoštovanja pravila zajedničkog upravljanja zakonodavac propisuje raznovrsne sankcije koji se ne temelje na ideji ništetnosti takvog ugovora, već na manje strogoj ideji njegova pobijanja. Štoviše, pobojnost je ograničena na nekretnine i registrirane pokretnine i to uz vrlo kratki zastarni rok. Nasuprot tomu, kad se radi o nedopuštenom prijenosu vlasništva pokretnina, bračni drug koji je poduzeo takvu radnju mora prije svega poduzeti radnje za povratak zajedničke stečevine u prvobitno stanje, a onda kad to nije moguće, mora isplatiti drugom bračnom drugu vrijednost kupljene pokretnine. Nadalje, ta struja u talijanskoj doktrini izvodi dodatne argumente iz članka 189. codice civilea kojim uređuje pitanja vezana za obveze koje su nastale odvojeno i gdje se izričito govori o „kvoti“" bračnoga druga.

Ipak veći dio talijanske doktrine protivi se takvom tumačenju. Među najsnažnijim argumentima kojima se suprotstavljaju ranije izloženoj interpretaciji jeste onaj da bračni drug koji nije sklopio ugovor kojim je stečeno vlasništvo nad određenom nekretninom ili registriranom pokretninom, svejedno može poduzeti radnje redovitog upravljanja nad stvari koju je kupio drugi bračni drug. Nadalje, dodatni je argument taj što stvar koju je stekao drugi bračni drug može biti predmetom založnog prava i za osobne obvezne odnose bračnog druga koji nije sudjelovao u kupnji stvari.

Dodatni se argument izvodi iz članka 94. bis Zakona o zemljišnim knjigama koji predviđa pravo upisa u korist oba bračna druga ako su odabrali režim zajedničke stečevine. Ipak valja naglasiti da ovaj argument ima vrlo ograničenu snagu s obzirom na to da se u Italiji zemljišnoknjižni sustav primjenjuje na ograničenom području, dok velika većina teritorija podliježe različitim pravilima javnog registra koji upisom jamči deklarativnu funkciju, a ne konstitutivnu. ${ }^{54}$ Talijanski pravni sustav ima, dakle, dvovrsni sustav evidentiranja nekretnina s različitim posljedicama po nastavku prava vlasništva.

Dodatne interpretativne dvojbe proizlaze iz činjenice da se zajednička stečevina uređuje isključivo strogim propisima, što dovodi do posljedice da je mogući predmet zajedničke stečevine u cijelosti tipiziran, pa stranke ne mogu ni o čemu sporazumno odlučivati. Zakonodavac nije niti dijelom predvidio uređenje ove materije putem dispozitivnih normi. Krutost ovih pravnih rješenja doima se posve neusklađena s rastućim trendovima povećanja autonomije volje strankama, odnosno u ovom slučaju bračnim drugovima. Nemogućnost oblikovanja imovinskog režima zajedničke stečevine odražava se na krutost položaja bračnog druga, koji iako ne sudjeluje u pravnom poslu kojim se stječe određenu stvar, postaje ipso iure sunositelj svih prava koja imaju za predmet stvar koja je ušla u zajedničku stečevinu.

Drugim riječima pekulijarnost ovog režima leži upravo u tomu što na temelju

53 Više u Mazzola, G., Re, M., Proposta di un diverso modo di intendere la comunione di beni tra coniugi, Riv. Notariato, 1978., str. 757.

54 Zemljišnoknjižni sustav, povijesno povezan s austrijskom pravnom kulturom za vrijeme Austro-Ugarske monarhije, preživio je u Italiji tek u nekoliko gradova na sjeveroistoku Italije. Među većima: Trst, Gorica, Trento i Bolzano.

Više o zemljišnoknjižnom sustavu u Italiji: Gabrielli, G., Tommaseo, F., Commentario della Legge tavolare, Milano, Giuffrè, 1989. 
pravnog posla kojeg je poduzeo samo jedan bračni drug, nastaje čitav niz prava za drugoga bračnog druga. Različita su tumačenja ovog ,,automatskog“ stjecanja prava. Prema jednom stajalištu pravni posao kojim se stječe stvar proizvodi automatsko stjecanje u korist drugoga bračnog druga, ako je prvi poduzeo pravni posao u ime i za račun zajedničke stečevine. Ova se teorija temelji na zastupništvu i na neki se način povezuje s onim stajalištima doktrine prema kojima zajednička stečevina ima svoju samostalnost. ${ }^{55}$ Naime, gleda se na stečevinu kao na subjekt koji je nositelj određenih i odvojenih prava i obveza. U ovoj bi perspektivi to značilo da svaki bračni drug djeluje u svojstvu zastupnika tog odvojenog subjekta koji ima za predmet zajedničku stečevinu.

$\mathrm{Na}$ temelju druge teorije stjecanje u odnosu na bračnog druga koji nije sudjelovao u pravnom poslu djelovalo bi ex lege. Teoretizira se postojanje automatske konverzije pravnih posljedica stjecanja prava u korist bračnog druga koji nije sudjelovao u pravnom poslu. Očita je analogija između položaja bračnog druga koji nije sudjelovao u pravnom poslu i položaja subjekta u ugovoru u korist trećeg. Iznova se može primijetiti krutost imovinskog režima zajedničke imovine. Automatizam učinaka onemogućuje drukčiji sporazum među bračnim drugovima. Jedini slučaj kada ne bi bilo tog automatizma jeste onda kad bi bračni drug u stjecanju određenih dobara uložio sredstva koja potječu iz vlastite imovine. No, to po definiciji ne pripada uređenju zajedničke stečevine tako da se ne može smatrati iznimkom.

\subsection{Odgovornost bračnih drugova prema člancima 189. i 190. codice civilea}

Složenost pravnog uređenja zajedničke stečevine može se najbolje uočiti čitajući članke 189. i 190. codice civilea. Prema članku 189., stavak 1., c.c., svaki bračni drug odgovara imovinom koja ulazi u zajedničku stečevinu tek supsidijarno i to do visine vrijednosti koja odgovara udjelu bračnog druga koji se obvezao, a sve to u slučaju obveza koje su nastale zbog nepoštovanja pravila o izvanrednom upravljanju zajedničkom stečevinom ili, prema čl. 189., stavak 2., c.c. radi ispunjenja obveza nastalih radi zadovoljavanja potreba različitih od obiteljskih interesa. Većina autora smatra da je zakonodavac u ovoj odredbi definirao udjele s isključivim ciljem definiranja krovnog ograničenja unutar kojeg vjerovnici mogu naplatiti svoju tražbinu koja proizlazi iz obveze koja nije preuzeta radi zadovoljavanja obiteljskih interesa. S time u vezi, prepoznaje se važan problem u tumačenju i primjeni načela supsidijarnosti. ${ }^{56}$ Postoje više različitih tumačenja ove odredbe. Na temelju prvog, vjerovnik prije pokretanja ovrhe nad imovinom koja je dio zajedničke stečevine, mora pokušati naplatiti tražbinu nastalu na temelju obveze, koja nije preuzeta u interesu obiteljske zajednice iz vlastite imovine bračnog druga koji je njegov dužnik i samo ako se njegov pokušaj naplate pokaže neuspješnim mogao bi supsidijarno pokrenuti ovrhu

55 De Paola, V., Macrì, A., Il nuovo regime patrimoniale della famiglia, Milano, Giuffrè, 1978., str. 198; Attardi, A., Profili processuali della comunione legale dei beni, Rivista di diritto civile, 1979., I, str. 25-51 (35).

56 Supsidijarnost koju ne predviđa hrvatski obiteljski zakonodavac. 
nad zajedničkom stečevinom. ${ }^{57}$ Prihvatiti ovo tumačenje značilo bi uvelike otežati položaj vjerovnika, koji bi morao dokazati neuspješni pokušaj naplate iz sredstava vlastite imovine bračnog druga/dužnika. Radilo bi se o teško prihvatljivom teretu dokazivanja, posebno imajući u vidu doista neučinkoviti postojeći sustav publiciteta imovinskih režima u talijanskom pravu. ${ }^{58}$

$\mathrm{Na}$ temelju drugog tumačenja, kako bi se poštovalo načelo supsidijarnosti dovoljno je zadovoljiti, tzv. beneficium ordinis. Vjerovnik bi mogao tražiti naplatu nad imovinom iz zajedničke stečevine, samo nakon što je zatražio od vjerovnika informaciju o postojanju eventualnih dobara iz vlastite imovine. ${ }^{59}$

Međutim, čini se da u talijanskoj doktrini prevladava tumačenje na kojim je supsidijarnost iz članka 189. c.c. jednostavno izraz izbora bračnog druga / dužnika tražiti, tzv. beneficium excussionis, navodeći vlastitu imovinu na kojoj će naplatiti tražbinu ako vjerovnik nije upoznat s postojanjem takve imovine. Doktrina nalazi dodatne argumente za prihvaćanje ove teorije u činjenici da postoje mnoge druge odredbe u talijanskom codice civileu kojima se uređuje beneficium excussionis, poput odredaba u dijelu koji se bavi obveznim pravom te trgovačkim pravom.

Nesporno je kako u ovom kontekstu prijepore i dvojbe izaziva ne toliko položaj bračnog druga/dužnika, već položaj drugog bračnog druga koji nije dužnik. S time u vezi, i u talijanskom je pravu uvriježena pravna regula kojom je odgovornost uvijek povezana s dugom. Ipak, tumačeći članak 189. c.c. nije nimalo razvidna poveznica između odgovornosti i duga. Štoviše dalo bi se zaključiti baš suprotno, odnosno da svaki put kad je obvezni odnos nastao zbog interesa koji se razlikuju od onih obiteljskih, bračni drug koji nije dužnik odgovara bez da se njemu može imputirati nastanak duga. Položaj bračnog druga koji nije dužnik mogao bi se dakle usporediti s položajem jamca tuđeg duga. Bračni drug koji nije dužnik snosi dio odgovornosti, što zakonodavac opravdava u postojanju zajednice života, kao osnovnog obilježja braka i posljedično u povjerenju kojeg treći vjerovnici polažu u solventnost bračnog druga s obzirom na njegov bračni status.

Konačno, neovisno o tumačenju koje će se odabrati za pojam supsidijarnosti, posve je razvidno kako su dobra iz zajedničke imovine izravno ovršiva na temelju naslova kojeg vjerovnik ima prema bračnom drugu/dužniku. Naime, vjerovniku nije potreban neki dodatni ili specifični naslov da bi pokrenuo ovršni postupak u odnosu na drugoga bračnog druga (koji nije dužnik) ili, prema ranije spomenutoj teoriji, prema zajedničkoj imovini koja je gledana poput zasebnoga pravnog subjekta. S time u vezi valja zaključiti da ovrha koju je pokrenuo vjerovnik nad imovinom koja ulazi u zajedničku stečevinu ne može se nikako smatrati kao ovrha ultra partes, već kao ovrha kojom se tereti bračnog druga dužnika koji odgovora i s udjelom iz zajedničke imovine.

57 Sveobuhvatnu analizu nudi Gabrielli, G., I rapporti patrimoniali tra coniugi, Trieste, Libreria la Goliardica, 1981., str. 152.

58 Usp. Russo, T. V., Obbligazioni familiari e responsabilità patrimoniale nel regime di comunione legale, Napoli, ESI, 2004., str. 50.

59 Više u: Volpe, V., La responsabilità patrimoniale dei coniugi in regime di comunione legale, u: Bonilini, G., (ur.), Trattato di diritto di famiglia, II, Il regime patrimoniale della famiglia, Milano, 2016., str. 1438. 
Članak 189. c.c. izaziva, dakle, doista velike prijepore u kontekstu tumačenja imovinske odgovornosti zajedničke stečevine. Vjerovnik jednog od bračnih drugova ne samo što može tražiti naplatu nad vlastitom imovinom bračnog druga dužnika na temelju općih pravila talijanskog obveznog prava (čl. 2740. c.c.) već može supsidijarno ovršiti zajedničku stečevinu do postignuća visine udjela bračnog druga/dužnika. ${ }^{60}$ Međutim, člankom 189. codice civilea ne pojašnjava koji je konkretan predmet ovrhe, odnosno konkretna stvar na kojoj bi se mogla ostvariti mjera osiguranja tražbine. Jedino što nije sporno jest činjenica da predmetom ovrhe ne može biti cjelokupni udio u zajedničkoj stečevini budući da bi to dovelo do raskida zajedničke stečevine. Naime, prema čl. 191. c.c. okolnosti razvrgnuća stečevine moraju biti izričito propisane zakonom, s obzirom na to da se radi o taksativnim slučajevima, a ovrha cjelokupnog udjela zajedničke stečevine nije nabrojena među takvim okolnostima razvrgnuća, premda bi u biti dovela do tog rezultata. Nadalje, doktrina ističe da kad bi treći vjerovnik ovrhom preuzeo udio zajedničke stečevine bračnog dužnika, de facto bi ušao u zajedničku stečevinu s drugim bračnim drugom koji nije dužnik, što bi dovelo do (neprihvatljive) posljedice da bi imovinski režim uređen odredbama obiteljskoga prava postojao među osobama koje nisu u brak ili u različitom obliku obiteljskog života. Drugim riječima, među dva subjekta čiji odnos nema ona temeljna i specifična obilježja zbog kojih uopće uživaju pravo uređenja njihovih odnosa prema obiteljskom zakonodavstvu. Nelogičnost i neracionalnost ovoga pravnog rješenja potaknule su talijansku doktrinu i sudsku praksu za potragom druge interpretacije članka 189. c.c. Prema jednom od predloženih alternativnih tumačenja ovrha bi trebala imati za predmet udio bračnog druga koji se odnosi na određenu stvar, a ne na cijelu zajedničku (idealnu) stečevinu. ${ }^{61}$ Prema tom razmišljanju predmetom ovrhe bi se mogao smatrati isključivo određeni materijalni dio određene stvari koji bi se u prirodi mogao dijeliti ili udio određenog dobra ili polovica zarade ako je određena stvar prodana na dražbi. ${ }^{62}$ Međutim, niti ova interpretacija nije zadovoljavajuća, budući da ostatak talijanske doktrine smatra da se time umanjuje zajednička stečevina, s obzirom na to da će se preostala imovina (nakon naplate vjerovnika) ponovno dijeliti među bračnim drugovima, što bi značilo umanjiti udio bračnog druga koji nije dužnik.

Stoga se pokušalo ponuditi još drukčije čitanje ove kompleksne odredbe. Poneki autori drže da bi ovrha mogla imati za predmet određena dobra zajedničke stečevine koja bi mogla biti ovršiva u cijelosti, ali zbog namirenja duga do iznosa koji odgovara udjelu bračnog druga/dužnika. ${ }^{63}$ Valja zaključiti da je prilično teško protumačiti članak 189. c.c. te da su pokušaj sustavne interpretacije čitavog instituta zajedničke stečevine prilično bezuspješni. Radi usklađenja pravila o ovrsi nad zajedničkom stečevinom i osnovanosti ovršnog postupka u odnosu na subjekta različitog od onoga koji je

60 U tom pogledu v. presudu Kasacijskog suda (ujedinjena vijeća) 4. kolovoza 1998., br. 7640, u: Corriere Giuridico, 1999., str. 204, s osvrtom De Paola, V.

61 Ex plurimis, v. Schlesinger, P., sub art. 189, Commentario alla riforma del diritto di famiglia, str. 789; Busnelli, D., La "comunione legale" nel diritto di famiglia riformato, Rivista del notariato, 1976., str. 43.

62 Usp. Finocchiaro, A., Finocchiaro, M., Diritto di famiglia, I, Milano, 1985., str. 1109.

63 V. Cian, G., Villani, A., Comunione dei beni tra coniugi (legale e convenzionale), in Rivista di diritto civile, 1980, I, str. 173. 
odgovoran za ispunjenje činidbe, a to bi reći na bračnog druga koji nije dužnik, doima se nužnim iznova protumačiti pojam zajedničke stečevine u talijanskom obiteljskom pravu. Na tom tragu kreće talijanski Kasacijski sud pojašnjavajući da sunositeljstvo prava u zajedničkoj stečevini ne djeluje manente comunione te da postaje subjektivno pravo samo nakon što se pojavila jedna od okolnosti za razvrgnuće zajedničke imovine prema članku 191 c.c. ${ }^{64}$ Tijekom trajanja zajedničke imovine bračni bi drugovi prema ovom tumačenju imali isključivo pravno očekivanje, koje bi se tek nakon (eventualnog) prestanka zajedničke stečevine pretvorilo u pravo na sunositeljstvo. Dodatno važno pojašnjenje $u$ tom pogledu nudi talijanski Ustavni sud koji je presudom br. 311 iz 1988. pojasnio da bračni drugovi nisu nositelji prava na udio, već da su solidarno titulari prava koje ima za predmet dobra iz zajedničke stečevine. ${ }^{65}$ Upravo na temelju ove presude dio doktrine smatra da se određena stvar u zajedničkoj stečevini može ovršiti u cijelosti. ${ }^{66}$

\subsection{Obveze preuzete u interesu obitelji i supsidijarna odgovornost vlastitom imovinom}

Normativne aporije koje se pojavljuju u tumačenju režima zajedničke stečevine dodatno su vidljive kad se uzme u obzir odredba članka 190. c.c. Radi se o odredbi koja je sadržajno simetrična članku 189., budući da propisuje da vjerovnici zajedničke stečevine, odnosno vjerovnici u obveznim odnosima koji su nastali radi zadovoljavanja određenog obiteljskog interesa, mogu se za polovicu duga zadovoljiti na vlastitoj imovini bračnih drugova. Ova odredba zrcali prethodnu: za obveze nastale za interese različitih od obiteljskih, vjerovnici se do određene visine mogu zadovoljiti i na imovini zajedničke stečevine. Dok je u ovom slučaju oprečno: za obveze nastale radi zadovoljavanja interesa obitelji, vjerovnici se do iznosa od pola duga mogu naplatiti i iz vlastite imovine bračnih drugova. Napose, članak 186 c.c. nabraja koje su to sve obveze za koje se u prvom redu odgovara zajedničkom imovinom. Drugim riječima, talijanski zakonodavac nabraja koje su to konkretne obveze koje mogu nastati radi zadovoljavanja interesa obitelji, a to su: svi eventualni tereti i založna prava koja postoje nad dobrom u trenutku stjecanja vlasništva nad njemu, sve obveze koje proizlaze iz upravljanja zajedničkom stečevinom, svi troškovi uzdržavanja obitelji, svi troškovi obrazovanja i odgoja djece te sve obveze koje su i odvojeno preuzeli bračni drugovi, a koje su u interesu obitelji. Ova posljednja kategorija obveza „u korist obitelji“ zadala je mnoge interpretativne muke. Naime, nedostaju jasne normativne smjernice o važnosti „obiteljskog interesa“ i pitanja na koji način vjerovnik koji ulazi u doticaj s bračni drugom može znati obvezuje li se taj dužnik radi zadovoljavanja obiteljskog interesa ili ne. Postoji više teorija u doktrini u tumačenju tog pojma. Na temelju prve smatra se da bi se kvalifikacija obveze (u

64 Misli se na presudu Kasacijskog suda 23. lipnja 1998., br. 6234.

65 Radi se o presudi Ustavnog suda 10. ožujka 1988., br. 311, u Diritto di famiglia e delle persone, 1988., str. 715. Prema stajalištu Suda bračni su drugovi sunositelji prava koji ima za predmet dobra koja ulaze u zajedničku stečevinu.

66 O tomu v. više u Gabrielli, G., Cubeddu, M.G., Il regime patrimoniale dei coniugi, Milano, Giuffrè, 1997., str. 172. 
korist obitelji ili ne) mogla odrediti u trenutku sklapanja posla ex ante procjenom vjerovnika koji bi na temelju „zdravog razuma“ i „društvene procjene“ mogao odrediti je li obveznopravni odnos motiviran zadovoljavanjem interesa obitelji. Druga pak teorija zagovara kao jedino rješenje ex post procjenu, razmatrajući in concreto namjenu koju su bračni drugovi odredili usluzi ili dobru kojeg su ugovorili. Razvidno je kako obveze nastale radi zadovoljavanja interesa obitelji ne odgovaraju obvezama koje su nastale prema članku 143 c.c. Naime, kao što smo već ranije isticali, članak 143. c.c. propisuje obvezu pridonošenja potrebama obitelji. Nesporno je u talijanskoj doktrini da su pojmovi obiteljskih „potreba“ (čl. 143. c.c.) te obiteljskih „interesa“ (članci 189. i 190. c.c.) različiti. Potrebe označavaju uži pojam kojeg smo u tom dijelu rada s razlogom i vezivali s pojmom egzistencije; dok interesi obitelji mogu biti i oni koji šire zadovoljavaju prohtjeve koji nisu nužni radi egzistencije. Primjerice, moglo bi se postaviti pitanje nastaje li zbog kupnje drugog televizora obveza za koju se može tvrditi da je preuzeta radi zadovoljavanja interesa obitelji. Razvidno je da o toj kvalifikaciji ovisi način i omjer kojim će bračni drugovi zajedničkom stečevinom i vlastitom imovinom odgovarati trećim vjerovnicima. Posljedično ta kvalifikacija može utjecati i na sastav zajedničke imovine, pa i na eventualni odabir različitog režima imovinskih odnosa u obitelji. Ako je obveza nastala radi zadovoljavanja interesa obitelji, vjerovnik se može naplatiti iz zajedničke imovine, ali također iz vlastite imovine bračnog druga/dužnika te bi dodatno mogao tražiti naplatu, do iznosa od polovice duga, iz vlastite imovine drugoga bračnog druga. Naprotiv, kad su dužnici u obveznopravnom odnosu radi zadovoljavanja interesa obitelji oba bračna druga, ako bi imovina iz zajedničke stečevine bila nedovoljna, oboje odgovaraju solidarno i u cijelosti za nastali dug. ${ }^{67}$

Dodatne interpretativne probleme zadaje posljednja kategorija obveza iz članka 186. c.c. za koju također bračni drugovi odgovaraju zajedničkom imovinom. Radi se o obvezama koje su bračni drugovi preuzeli „zajednički“. Tu se postavlja pitanje treba li predmnijevati da je svaka obveza „zajednički“ preuzeta ujedno i nastala radi zadovoljavanja interesa obitelji? Takvo tumačenje nije prihvatljivo s obzirom na to da bi se time podvelo pod interese obitelji i možebitne sebične interese jednog ili oba bračna druga koji ne odgovaraju interesima obitelji, a to je posebno osjetljivo pitanje ako postoje djeca. Primjerice, bračni drugovi mogli bi sklopiti vrlo skupi ugovor o putovanju, jamčeći isplatu iz imovine zajedničke stečevine, a tek supsidijarno odgovarati s vlastitom imovinom. Time bračni drugovi izričito isključuju mogućnost različite namjene imovine zajedničke stečevine, koju bi se, primjerice, moglo založiti za ostvarenje pravnih interesa (pa štoviše i egzistencijalnih potreba) obitelji. Snažan protuargument takvom restriktivnom tumačenju mogla bi biti autonomija volje bračnih drugova. Ipak, tomu bi se moglo oponirati da i sloboda ugovaranja nailazi na određena ograničenja koja se odnose na opravdanost interesa konkretnog ostvarivanja volje stranaka. Je li opravdano pozivati se na slobodu ugovaranja u cilju terećenja zajedničke stečevine radi ostvarenja interesa koji nisu obiteljski? Naime, u talijanskom obiteljskom pravu postavlja se pitanje graniči li takvo ponašanje bračnih drugova sa zloupotrebom koju bi valjalo privatnopravno sankcionirati s obzirom na

67 V. Tribunale Bergamo, 21. siječnja 2002., u: Giurisprudenza italiana, 2002., c. 1866. 
to da ugrožava interese djece. Potpuno je neupitno da je najbolji interes djeteta temelj uređenja bilo kojega modernog obiteljskog zakonodavstva.

Zaključno, valja naglasiti da je u talijanskom obiteljskom pravu odgovornost propisana člankom 190. c.c., poput one iz članka 189 c.c., neodgodive prirode. Stoga su ništetne sve klauzule kojima se predviđa odricanje od primjene čl. 190. c.c. S time u vezi sudska je praksa zabranila korištenje u bankarskim ugovorima općih klauzula s kojima se dopušta banci (vjerovniku) prioritetno, a ne tek supsidijarno, naplaćivanje duga iz vlastite imovine svakoga bračnog druga.$^{68}$ Prema doktrini takva restriktivna teorija koja proizlazi iz sudske prakse, dovodi do ništetnosti, pozivajući se na potrebu poštovanja načela par condicio creditorum i u nemogućnosti izmjene zakonskog režima zajedničke stečevine koji, kao što se već ranije spominjalo, propisuje kruti okvir strogih normi. ${ }^{69}$

\section{ZAKLJUČNA RAZMATRANJA}

Provedeno je istraživanje dokazalo da postoje bitne razlike dvaju sustava u pogledu uređenja imovinskih odnosa u obitelji. S jedne strane, razvidno je da hrvatski sustav, usporedno s talijanskim, dopušta bračnim drugovima (kao i izvanbračnim drugovima i istospolnim partnerima) veću autonomiju u izražavanju volje u reguliranju međusobnih imovinskih odnosa. $\mathrm{U}$ tom pogledu, $\mathrm{u}$ radu se istaknulo da talijansko pravo ne predviđa mogućnost sklapanja bračnog ugovora nalik hrvatskome, već dopušta, primjenom nekoliko alternativnih normi koja su prilično kruto postavljena u zakonodavstvu, relativno ograničenu mogućnost izražavanja autonomije volje. Nadalje, uočava se da talijanski pravni sustav, za razliku od hrvatskoga, koji se u tom pogledu unaprijedio, i dalje uređuje režim zajedničke stečevine prema pravilima koja bismo mogli usporediti sa zajedničkim vlasništvom, a ne suvlasništvom što zadaje znatne probleme u praktičnoj primjeni i u odnosima među bračnim drugovima i osobito u odnosima s trećim osobama, čiji položaj nije dovoljno zaštićen. Dalo bi se zaključiti da je u tom pogledu poštena treća osoba bolje zaštićena u hrvatskom pravnom poretku, iako u domaćem pravu, za razliku od talijanskog, nedostaje bilo koji oblik publiciteta obiteljskih imovinskih režima. Nadalje, uočava se da talijanski pravni sustav mnogo detaljnije uređuje pitanja odgovornosti bračnih drugova u odnosu na treće. Ipak, budući da je taj dio uređenja imovinskih odnosa tek nedavno ponovno izričito normirano u hrvatskom pravu, vjerujemo da će i to pitanje kroz buduću sudsku praksu pronaći detaljnije tumačenje i odgovore na pitanja postavljena u radu, a koja se u oba sustava odnose na kvalifikaciju obveza za potrebe ili u interesu obitelji i na pitanje supsidijarnosti u naplati tražbine. Zajednički zaključak do kojeg se dolazi i posljedično prijedlozi de lege ferenda koji proizlaze, a o kojima bi valjalo razmisliti, odnose se na potrebu veće informiranosti nevjeste i ženika, odnosno bračnih drugova, o sadržaju i uređenju imovinskih odnosa i na još veću potrebu publiciteta imovinskih

68 Usp. Corte d'Appello Roma, 7. svibnja 2002., Rivista di diritto civile, 2003., str. 535, s osvrtom Bozzi, L.

69 U tom pogledu Paladini, M., sub art. 190 c.c., u Commentario del codice civile, Di Rosa, G., (ur.), Torino, UTET, 2018., str. 1457. 
režima bračnih drugova (i drugih izvanbračnih drugova i istospolnih partnera na koje se taj sustav primjenjuje) radi omogućavanja poštenim trećima stjecanje oportunih informacija o imovini njihovih potencijalnih i realnih dužnika. Uostalom, tu potrebu ističe i europski zakonodavac, svjestan mogućeg problema, u preambuli Uredbe da izbor bračnih drugova mora biti „informiran“. Stupanjem na snagu ranije spomenutih uredaba ovo će se pitanje nametnuti s obzirom na to da će se s mogućnošću odabira mjerodavnog prava među različitim pravnim sustavima, koji su na određene načine prema uredbi povezani s bračnim drugovima (ili registriranim partnerima), koji bilježe prekogranične implikacije, ukazati čitav niz različitosti shodno odabiru primjene među različitim pravima. Kad se na to gleda iz perspektive bračnih drugova moglo bi se priupitati jesu li oni uopće upoznati s posljedicama koje bi se mogle pojaviti zbog odabira jednog, drugog ili nekog trećeg sustava koji bi mogli doći u obzir prema rješenjima predviđenima uredbom. Ergo, postavlja se pitanje koje će biti realne posljedice za bračne drugove (s prekograničnim implikacijama) koji će izabrati neko drugo pravo, s obzirom na to da praksa ukazuje da je njihova informiranost već glede domaćeg prava (kojeg bi trebali najbolje poznavati) vrlo ograničena. Hoće li ta sloboda biti kontraproduktivna za zaštitu njihovih interesa ili ne? Kad se na to gleda iz perspektive trećih osoba postavlja se pitanje posljedica nedostatka publiciteta imovinskih režima na njihova stečena prava. Dobro znamo koliko je interpretativnih napora hrvatska sudska praksa uložila, kao uostalom i talijanska, za pronalaženje balansa između zaštite stečenih prava bračnih drugova s jedne strane i trećih s druge, a da to ne prejudicira pravnu sigurnost i protočnost pravnog prometa. Sad, kad bi se taj problem ,pretočio“" na prekograničnu razinu, shvaća se kako nedostatak publiciteta imovinskih režima uvelike može utjecati na prava trećih. Dostatno je zamisliti koliko bi napora treća osoba morala uložiti za pratiti tijek dobara bračnih drugova s prekograničnim implikacijama u cilju naplate vlastite tražbine. Sumirajući različitosti u uređenju bračnih imovinskih sustava od države članice do države članice, a autorice su se u ovom radu dotaknule tek hrvatskog i talijanskog sustava, s nedostatkom adekvatnog publiciteta postojećih režima (zakonskih i ugovornih) realno je očekivati probleme u primjeni i/ili eventualne nepoželjne pojave različitih, dvojakih tumačenja imovinskih odnosa s prekograničnim implikacijama naspram onih s nacionalnim obilježjima.

\section{LITERATURA}

Knjige i članci:

1. Alinčić, Mira, Bakarić, Ana, Porodično pravo, 3. izd., Zagreb, Narodne novine, 1989.

2. Alinčić, Mira, Bakarić-Mihanović, Ana, Porodično pravo, Zagreb, Pravni fakultet, Centar za stručno usavršavanje i suradnju s udruženim radom, 1980.

3. Attardi, Aldo, Profili processuali della comunione legale dei beni, Rivista di diritto civile, 1979., I, str. 25-51.

4. Bakarić-Abramović, Ana, Hrabar, Dubravka, Imovinski odnosi, Obiteljsko pravo, Birotehnika CDO, Zagreb, 1994., str. 378-395.

5. Belaj, Vlado, Bračna stečevina po obiteljskom zakonu, Zbornik Pravnog fakulteta Sveučilišta u Rijeci, v. 23., 1/2002, str. 179-200. 
6. Belaj, Vlado, Stjecanje imovine (vlasništva) u bračnoj i izvanbračnoj zajednici, Zbornik Pravnog fakulteta Sveučilišta u Rijeci, v. 26, 1/2005, str. 339-365.

7. Bruno, Paolo, Le controversie familiari nell'Unione Europea. Regole, fattispecie, risposte, Milano, Giuffrè, 2018.

8. Busnelli, Donato, La "comunione legale" nel diritto di famiglia riformato, Rivista del notariato, 1976.

9. Cian, Giorgio, Villani, Alberto, Comunione dei beni tra coniugi (legale e convenzionale), Rivista di diritto civile, 1980., I, str. 337-412.

10. Confortini, Massimo, La comunione convenzionale tra coniugi, Il diritto di famiglia, Trattato Bonilini-Cattaneo, II, Torino, 2007.

11. Crnić, Jadranko, Končić, Ana-Marija, Utjecaj propisa o bračnoj stečevini te učincima izvanbračne zajednice na povjerenje u zemljišne knjige, Informator, br. 5487-5488, str. 1-9.

12. Cubeddu, Maria Giovanna, La pubblicità del regime dei beni e la scelta della legge applicabile, Famiglia, Persone, 2008.

13. Čulo, Anica, Radina, Ana, Valjanost bračnog ugovora, u: Rešetar, Branka, Župan, M., Imovinskopravni aspekti razvoda braka - hrvatski, europski i međunarodni kontekst, Osijek, Pravni fakultet u Osijeku, 2011., str. 139-163.

14. Čulo, Anica, Šimović, Ivan, Registar bračnih ugovora kao doprinos sigurnosti u pravnom prometu, Zbornik Pravnog fakulteta u Zagrebu, god. 59, 5/2009, str. 1029-1068.

15. De Paola, Vincenzo; Macrì, Antonio, Il nuovo regime patrimoniale della famiglia, Milano, Giuffré, 1978.

16. De Rubertis, Giovanni, La comunione convenzionale tra coniugi, Rivista del notariato, 1989.

17. Dutta, Anatol, Weber, Johannes, Die Europäischen Güterrechtsverordnungen, München, Beck, 2017.

18. Finocchiaro, Alfio, Finocchiaro, Mario, Diritto di famiglia, I, Milano, Giuffrè, 1985.

19. Gabrielli, Giovanni, I rapporti patrimoniali tra coniugi, Trieste, libreria Goliardica, 1981.

20. Gabrielli, Giovanni, Cubeddu, Maria Giovanna, Il regime patrimoniale dei coniugi, Milano, Giuffré, 1997.

21. Gabrielli, Giovanni, Tommaseo Ferruccio, Commentario della Legge Tavolare, Milano, Giuffrè, 1989.

22. Grasso, Biagio, La comunione convenzionale, Trattato Rescigno, 3, Torino, UTET, 1996.

23. Hrabar, Dubravka, Retroaktivnost i stečena prava prema obiteljskom pravu, Hrvatska pravna revija, 5/2005, str. 38-46.

24. Hrabar, Dubravka, Režim stjecanja i diobe imovine bračnih drugova u hrvatskom i poredbenom pravu, Zbornik Pravnog fakulteta u Zagrebu, 44, 3/1994, str. 235-252.

25. Hrabar, Dubravka, Status imovine bračnih drugova - neka pitanja i dvojbe, Godišnjak 9 , Aktualnosti hrvatskog zakonodavstva i pravne prakse, Organizator, Zagreb, 2002., str. 43-62.

26. Ivančić-Kačer, Blanka; Klasiček, Dubravka, Bračni ugovor - neka otvorena pitanja, u: Hrabar, Dubravka (ur.), Odabrane teme iz građanskog i obiteljskog prava, Zagreb, Pravni fakultet Sveučilišta u Zagrebu, 2008., str. 1-30.

27. Kačer, Hrvoje, (Izvan)bračna stečevina i zemljišne knjige - neka pitanja i dvojbe, Zbornik Pravnog fakulteta u Zagrebu, 55, 3-4/2005, str. 1037-1074.

28. Kačer, Hrvoje, Jedna dvojba glede primjene ObZ ili imaju li odredbe ObZ o bračnoj stečevini povratni učinak, Pravo i porezi, god. 8., 12/1999, str. 26-32.

29. Klarić, Petar; Vedriš, Martin, Građansko pravo, Zagreb, Narodne novine, 2008.

30. Korać Graovac, Aleksandra, Imovinski odnosi, u: Alinčić, M., i dr., Obiteljsko pravo, Zagreb, Narodne novine, 2007., str. 495-533. 
31. Lagarde, Paul, Règlements 2016/1103 et 1104 du 24 juin 2016 sur les régimes matrimoniaux et sur le régime patrimonial des partenariats enregistrés, Rivista di diritto internazionale privato e processuale, 2016., str. 676-686.

32. Majstorović, Irena, Bračni ugovor: novina hrvatskog obiteljskog prava, Zagreb, Pravni fakultet u Zagrebu, 2005.

33. Mazzola, G.; Re, M., Proposta di un diverso modo di intendere la comunione di beni tra coniugi, Riv. Notariato, 1978.

34. Mladenović, Marko, Porodično pravo, knjiga II, Beograd, Privredna štampa, 1981.

35. Oberto, Giacomo, I contratti della crisi coniugale, l'autonomia negoziale nei rapporti patrimoniali tra coniugi (non in crisi), Familia, 2003.

36. Patti, Salvatore, Cubeddu, Maria Giovanna, Introduzione al diritto della famiglia in Europa, Milano, Giuffrè, 2008.

37. Perlingieri, Giovanni, Interferenze tra unione civile e matrimonio. Pluralismo familiare e unitarietà dei valori normativi, Rassegna di diritto civile, 1/2018., str. 101-130.

38. Perlingieri, Pietro, Manuale di diritto civile, Napoli, Edizioni Scientifiche Italiane, 2018.

39. Pintens, Walter, Matrimonial property Law in Europe, u: Boele-Woleki i dr. (ur.), The Future of Family property in Europe, Cambridge - Antwerp - Portland, Intersentia, 2011., str. 19-46;

40. Prokop, Ana, Komentar osnovnom zakonu o braku, Zagreb, Školska knjiga, 1959.

41. Radolović, Aldo, Načelo povjerenja (pouzdanja) u zemljišnu knjigu i raspolaganje bračnom stečevinom - kritički prikaz i analiza recentne prakse u Republici Hrvatskoj i Republici Sloveniji, Hrvatska pravna revija, 5/2005, str. 61-66.

42. Rešetar, Branka; Josipović, Una, Sporna pitanja bračne stečevine s osvrtom na bankovne ugovore bračnih drugova, Zbornik Pravnog fakulteta u Splitu, 50, 1/2013., str. 115-138.

43. Russo, Tommaso Vito, Obbligazioni familiari e responsabilità patrimoniale nel regime di comunione legale, Napoli, ESI, 2004.

44. Santosuosso, Fernando, Delle persone e della famiglia. Il regime patrimoniale della famiglia, Commentario Codice civile, I, 1, Torino, 1983.

45. Trimarchi, Giuseppe, Le imprese dei coniugi, u: Perlingieri, P. (ur.), Trattato di Diritto Civile del Consiglio Nazionale del Notariato, Napoli, Edizioni Scientifiche Italiane, 2015.

46. Volpe, V., La responsabilità patrimoniale dei coniugi in regime di comunione legale, u: Bonilini, G., (ur.), Trattato di diritto di famiglia, II, Il regime patrimoniale della famiglia, Milano, 2016.

47. Winkler, Sandra, Il diritto di famiglia, u Benacchio, Gian Antonio; Casucci, Felice (ur.), Temi e Istituti di Diritto Privato dell'Unione Europea, Torino, Giappichelli, 2017., str. 293-316.

Pravni izvori:

1. Codice civile iz 1942. godine (Regio Decreto 16 marzo 1942 - XX, n. 262).

2. Obiteljski zakon NN, br. 103/2015.

3. Obiteljski zakon, NN, br. 116/03, 17/04, 136/04, 107/07, 57/11, 61/11, 25/13, 05/15

4. Obiteljski zakon, NN, br. $162 / 1998$

5. Obiteljski zakon, NN, br. 75/2014, 83/2014, 05/2015.

6. Osnovni zakon o braku, Službeni list FNRJ, br. 29/1946

7. Uredba Vijeća (EU) 2016/1103 o provedbi pojačane suradnje u području nadležnosti, mjerodavnog prava te priznavanja i izvršenja odluka u stvarima bračnoimovinskih režima, SL L 183, 8.7.2016.

8. Uredba Vijeća (EU) 2016/1104 o provedbi pojačane suradnje u području nadležnosti, mjerodavnog prava te priznavanja i izvršenja odluka u stvarima imovinskih posljedica registriranih partnerstava, SL L 183, 8.7.2016.

9. Ustav Republike Hrvatske, NN, br. 56/1990, 135/1997, 08/1998, 113/2000, 124/2000, 28/2001, 41/2001, 55/2001, 76/2010, 85/2010, 05/2014. 
10. Zakon o vlasništvu i drugim stvarnim pravima, NN, br. 91/1996, 68/1998, 137/1999, $22 / 2000,73 / 2000,129 / 2000,114 / 2001,79 / 2006,141 / 2006,146 / 2008,38 / 2009,153 / 2009$, $143 / 2012,152 / 2014$.

11. Zakon o zemljišnim knjigama, NN, br. 91/1996, 68/1998, 137/1999, 114/2001, 100/2004, $107 / 2007,152 / 2008,126 / 2010,55 / 2013,60 / 2013,108 / 2017$

12. Zakon o životnom partnerstvu osoba istog spola, NN, br. 92/2014.

13. Zakona o braku i porodičnim odnosima, Narodne novine, br. 11/1978, 27/1978, 45/1989 i $59 / 1990$

Sudska praksa:

1. Corte d'Appello Roma, 7. svibnja 2002., Rivista di diritto civile, 2003., str. 535.

2. Kasacijski sud Republike Italije, odluka 18. lipnja 1990., br. 6118, Corriere Giuridico, 1990., str. 1125.

3. Kasacijski sud Republike Italije, odluka 23. lipnja 1998., br. 6234.

4. Kasacijski sud Republike Italije, ujedinjena vijeća, odluka 4. kolovoza 1998., br. 7640, Corriere Giuridico, 1999., str. 204.

5. Kasacijski sud Republike Italije, ujedinjena vijeća, odluka 4. lipnja 1999., br. 5487, Notariato, 1999., str. 508.

6. Tribunale Bergamo, 21. siječnja 2002., Giurisprudenza italiana, 2002., c. 1866.

7. Ustavni sud Republike Italije, odluka od 10. ožujka 1988., br. 311, Diritto di famiglia e delle persone, 1988., str. 715.

8. Ustavni sud Republike Hrvatske, odluka od 14. lipnja 2011., U-III-103/2008.

9. Ustavni sud Republike Hrvatske, odluka od 13. listopada 2004., U-III-493/2002.

10. Vrhovni sud Republike Hrvatske, odluka od 7. veljače 2017., Rev X 29/2015-2;

11. Vrhovni sud Republike Hrvatske, odluka od 29. listopada 2013., Rev 1867/12-2.

12. Vrhovni sud Republike Hrvatske, odluka od 10. lipnja 2015., Rev 2097/2011-2.

13. Vrhovni sud Republike Hrvatske, odluka od 19. listopada 2005., Rev 142/2004.

14. Vrhovni sud Republike Hrvatske, odluka od 23. travnja 1997., Rev 2772/95.

15. Županijski sud u Splitu, odluka od 15. rujna 2016., Gž Ob-97/16.

16. Županijski sud u Varaždinu, odluka od 27. svibnja 2017., Gž Ovr-236/17-5.

17. Županijski sud u Splitu, odluka od 15. rujna 2016., Gž Ob-97/16. 


\author{
Lucia Ruggeri* \\ Sandra Winkler**
}

Summary

\title{
SOME ISSUES CONCERNING THE MATRIMONIAL PROPERTY REGIMES IN THE CROATIAN AND ITALIAN FAMILY LAW
}

The paper will analyse some issues concerning the matrimonial property regimes in the Croatian and Italian family law. Firstly, it will be examined the legal framework in the context of the matrimonial property regimes in the Croatian family law. Subsequently, these legal solutions will be compared with the Italian familial legislation, pinpointing the issues related to the practical implementation of the law concerning the matrimonial property regimes. Thereafter, taking into account the results of the first stage of the research, the paper will deal with the pro et contra of both familial legislations, which will result from the comparison of the two legal models. The purpose of this comparative research is to find out if there is a necessity to improve the existing legal framework in the context of the matrimonial property regimes. In the last part of the paper will be examined the results of this research in the light of the entrance into force of the two EU Regulations regarding the matrimonial property regimes and the property regimes of the registered partnerships. Indeed, coming into the force these Regulations will originate some new legal challenges related to the regulation of the familial property regimes having cross-borders implications. Finally, the paper will offer some possible new solutions in order to improve the legislation in force, especially regarding the property regimes of cross-border families.

Keywords: family; property regimes; matrimonial property agreement; spouses; partners; registered partnership; Regulation 2016/1103; Regulation 2016/1104.

* Lucia Ruggeri, Ph.D., Full Professor, University of Camerino, Faculty of Law; lucia.ruggeri@ unicam.it.

** Sandra Winkler, Ph.D., Assistant Professor, University of Rijeka, Faculty of Law; swinkler@ pravri.hr. 
Zussamenfassung

\section{MANCHE FRAGEN ZU DEN VERMÖGENSBEZIEHUNGEN DER EHEGATTEN IM KROATISCHEN UND ITALIENISCHEN FAMILIENRECHT}

Dieser Beitrag analysiert manche Fragen zu den Vermögensbeziehungen der Ehegatten im kroatischen und italienischen Familienrecht. Zuerst wird die bestehende Regelung von Vermögensbeziehungen der Ehegatten im kroatischen Familienrecht untersucht. Anschließend werden inländische Gesetzesbeschlüsse mit der italienischen Familiengesetzgebung im Kontext der Regelung von Vermögensbeziehungen in der Familie verglichen, wobei die wichtigsten Fragen, die bei der praktischen Anwendung der Beschlüsse zum Familienrecht auftauchen, hervorgehoben werden. Aufgrund gefundener Antworten wird im Beitrag durch die komparative Forschungsmethode versucht, die Vor- und Nachteile dieser zwei nationalen Gesetzesrahmen zu den Vermögensbeziehungen in der Ehe festzustellen, wobei die Frage gestellt wird, ob dieser Bereich ferner ausgearbeitet werden muss. Die Ergebnisse genannter Analyse werden im letzten Teil des Beitrags im Lichte des Inkrafttretens von zwei europäischen Verordnungen über Vermögensbeziehungen der Ehegatten und eingetragenen Partnerschaften ausgewertet, denn diesbezüglich werden neue rechtliche Herausforderungen auftauchen, die mit unterschiedlichen Fragen der Regelung von Vermögensbeziehungen in Familien mit grenzüberschreitenden Implikationen verbunden sind. Abschließend werden mögliche Lösungen geboten, welche die bestehende Regelung von Vermögensbeziehungen in der Familie verbessern würden, wobei besondere Betonung auf der grenzüberschreitenden Dimension dieser Beziehungen liegt.

Schlüsselwörter: Familie; Vermögensbeziehungen; Ehegatten; außereheliche Partner; Lebenspartnerschaft; Verordnung 2016/1103; Verordnung 2016/1104.

Riassunto

\section{ALCUNE QUESTIONI RELATIVE AI RAPPORTI PATRIMONIALI TRA CONIUGI NEI DIRITTI DI FAMIGLIA CROATO ED ITALIANO}

Nel presente lavoro si tratteranno alcune questioni relative ai rapporti patrimoniali tra coniugi nei diritti di famiglia croato ed italiano. Anzi tutto, si analizzerà la vigente disciplina giuridica nell'ambito dei rapporti patrimoniali tra coniugi nel diritto di famiglia croato. Di seguito, si compareranno le soluzioni giuridiche individuate con 
la normativa italiana di diritto di famiglia, individuando all'uopo le questioni aperte nell'applicazione pratica delle norme nell'ambito dei rapporti patrimoniali di famiglia. Nel prosieguo del lavoro le autrici sulla base delle risposte individuate attraverso un metodo comparato di ricerca, tenteranno di ricostruire un quadro delle qualità e delle lacune presenti nelle due legislazioni nazionali nel contesto dei rapporti patrimoniali tra coniugi, interrogandosi sull'opportunità di un'ulteriore evoluzione della disciplina giuridica in oggetto. Degli esiti dell'indagine condotta si avrà modo di trattare nella parte conclusiva del lavoro, e ciò in particolare alla luce dell'entrata in vigore dei due Regolamenti europei sui regimi patrimoniali dei coniugi e delle unioni registrate, in seguito alla quale affioreranno delle nuove sfide giuridiche collegate alla risoluzione di diverse questioni concernenti i rapporti patrimoniali nelle famiglie con implicazioni transnazionali. Nelle conclusioni le autrici offriranno possibili soluzioni con le quali si potrebbe migliorare la vigente disciplina giuridica principalmente con riferimento ai rapporti patrimoniali tra coniugi caratterizzati da implicazioni transnazionali.

Parole chiave: famiglia; rapporti patrimoniali; convenzione matrimoniale; coniugi; conviventi; unione registrata; Regolamento 2016/1103; Regolamento 2016/1104. 